Full length article

\title{
Three-species biofilm model onto plasma-treated titanium implant surface
}

\author{
Adaias O. Matos ${ }^{\mathrm{a}}$, Antônio P. Ricomini-Filho ${ }^{\mathrm{b}}$, Thamara Beline ${ }^{\mathrm{a}}$, Erika S. Ogawa ${ }^{\mathrm{a}}$, \\ Bárbara E. Costa-Oliveira ${ }^{b}$, Amanda B. de Almeida ${ }^{a}$, Francisco H. Nociti Junior ${ }^{a}$, \\ Elidiane C. Rangel ${ }^{c}$, Nilson C. da Cruz ${ }^{c}$, Cortino Sukotjo ${ }^{d}$, Mathew T. Mathew ${ }^{\mathrm{d}, \mathrm{e}}$, \\ Valentim A.R. Barão ${ }^{\text {a,* }}$ \\ a Department of Prosthodontics and Periodontology, Piracicaba Dental School, University of Campinas (UNICAMP), Av Limeira, 901, Piracicaba, São Paulo \\ 13414-903, Brazil \\ b Department of Physiological Science, Piracicaba Dental School, University of Campinas (UNICAMP), Av Limeira, 901, Piracicaba, São Paulo 13414-903, \\ Brazil \\ ${ }^{\mathrm{c}}$ Laboratory of Technological Plasmas, Engineering College, Univ Estadual Paulista (UNESP), Av Três de Março, 511, Sorocaba, São Paulo 18087-180, Brazil \\ d Department of Restorative Dentistry, University of Illinois at Chicago, College of Dentistry, 801 S Paulina, Chicago, IL 60612, USA \\ e Department of Biomedical Sciences, University of Illinois College of Medicine at Rockford,1601 Parkview Avenue, Rockford, IL 61107, USA
}

\section{A R T I C L E I N F O}

\section{Article history:}

Received 22 May 2016

Received in revised form

16 December 2016

Accepted 18 January 2017

Available online 21 January 2017

\section{Keywords:}

Micro-arc oxidation

Glow discharge plasma

Biofilms

Titanium

\begin{abstract}
A B S T R A C T
In this study, titanium (Ti) was modified with biofunctional and novel surface by micro-arc oxidation (MAO) and glow discharge plasma (GDP) and we tested the development of a three-species periodontopatogenic biofilm onto the treated commercially-pure titanium (cpTi) surfaces. Machined and sandblasted surfaces were used as control group. Several techniques for surface characterizations and monoculture on bone tissue cells were performed. A multispecies biofilm composed of Streptococcus sanguinis, Actinomyces naeslundii and Fusobacterium nucleatum was developed onto cpTi discs for $16.5 \mathrm{~h}$ (early biofilm) and $64.5 \mathrm{~h}$ (mature biofilm). The number of viable microorganisms and the composition of the extracellular matrix (proteins and carbohydrates) were determined. The biofilm organization was analyzed by scanning electron microscopy (SEM) and Confocal laser scanning microscopy (CLSM). In addition, MC3T3-E1 cells were cultured on the Ti surfaces and cell proliferation (MTT) and morphology (SEM) were assessed. MAO treatment produced oxide films rich in calcium and phosphorus with a volcano appearance while GDP treatment produced silicon-based smooth thin-film. Plasma treatments were able to increase the wettability of $\mathrm{cpTi}(\mathrm{p}<0.05)$. An increase of surface roughness $(\mathrm{p}<0.05)$ and formation of anatase and rutile structures was noted after MAO treatment. GDP had the greatest surface free energy $(p<0.05)$ while maintaining the surface roughness compared to the machined control $(p>0.05)$. Plasma treatment did not affect the viable microorganisms counts, but the counts of $F$. nucleatum was lower for MAO treatment at early biofilm phase. Biofilm extracellular matrix was similar among the groups, excepted for GDP that presented the lowest protein content. Moreover, cell proliferation was not significantly affected by the experimental, except for MAO at 6 days that resulted in an increased cell proliferative. Together, these findings indicate that plasma treatments are a viable and promising technology to treat bone-integrated dental implants as the new surfaces displayed improved mechanical and biological properties with no increase in biofilm proliferation.
\end{abstract}

(c) 2017 Elsevier B.V. All rights reserved.

\section{Introduction}

The oral cavity is colonized by different species of microorganisms, and as the teeth, all the materials used in oral rehabilitation

\footnotetext{
* Corresponding author.

E-mail address: vbarao@unicamp.br (V.A.R. Barão).
}

are also prone to microbial colonization [1]. The biofilm formed on dental implants may damage the substratum to which the microorganisms are adhered and may also be responsible for early implant failure caused by inflammations of peri-implant tissues. Around $10 \%$ of dental implant late-failure is caused by peri-implantitis $[2,3]$. The implant-abutment gap, poor oral hygiene, depth of periimplant sulcus and surface properties (i.e. roughness and surface free energy) of implant components are considered risk factors for 
peri-implantitis development [4,5]. Peri-implantitis can cause the loss of osseointegrated implant due to the chronic inflammation in supporting tissues [6,7]. Therefore, it is important to understand the relationship between biofilm formation and implant surface characteristics [8].

Biofilm formation on different substrata in the oral cavity begins by the adhesion of primary colonizers as Streptococcus spp. and Actinomyces spp. by interaction of the bacterial wall with the saliva film formed on the substrate $[9,10]$. The first adhered cells provide the link for the establishment of secondary colonizers by co-adhesion and co-aggregation of microorganisms, favoring cell number increase and biofilm tridimensional organization $[11,12]$. The composition of the pathogenic biofilm present in peri-implantitis is similar to the biofilm in periodontitis, where the genera Actinomyces, Streptococcus and Fusobacterium are reported to be health, core and periodontitis associated species $[7,13,14]$.

To enhance the success rate of dental implants, topographical and chemical surface modifications have been widely studied with the objective to increase the implant-bone contact, particularly in low-density bone tissue areas [15-17]. It is imperative that such surfaces control the proliferation of microorganisms to mitigate early and late implant failures. The micro-arc oxidation (MAO) is an emerging treatment technique to deposit an oxide layer on metals, including titanium (Ti). MAO is performed in an aqueous electrolyte coupled to the anode electrode, above the dielectric breakdown voltage and is accompanied by micro plasma discharges to the metal surface $[18,19]$. The oxide layer deposited on the metal confers greater resistance to wear and corrosion, producing thermal protection and having good adhesion to the material [20]. MAO treated surfaces promotes the creation of micropores, which accelerates bone formation and improves implant-bone contact [21,22]. Recent studies have demonstrated beneficial effects of incorporating calcium and phosphorus on increasing the corrosion resistance of Ti material [23], besides contributing to bone growth, calcification of the bone matrix and cell differentiation [24,25]; however, their effect on biofilm formation remains unexplored.

Another promising source of biomaterial surface treatment is the glow discharge plasma (GDP). It is a type of non-thermal plasma used to sterilize and to modify biomaterial surfaces at room temperature and low pressure $[26,27]$. This treatment changes the material surface and it is developed in atmosphere with highenergy electrons, ions, ultraviolet photons and reactive species. Besides being an efficient and economical method, GDP is attractive to promote treatment with depth limited to a few nanometers of the surface, which can modify the surface while maintaining the volume properties and metal function. Previous studies [28,29] have shown that GDP reduced the adhesion of Candida spp onto denture base acrylic resin in vitro. However, its influence on the development of periodontopathogenic multispecies-biofilm is still unknown.

Therefore, this study aimed to investigate the formation of three-species biofilm composed of $S$. sanguinis, A. naeslundii, $F$. nucleatum onto cpTi coated with MAO and GDP. The synthetized coatings were characterized using different techniques, including pre-osteoblastic (MC3T3-E1) monocultures.

\section{Materials and methods}

\subsection{Experimental design}

CpTi discs were randomly divided into four groups according to the surface treatments: machined $(\mathrm{M})$ and sandblasted $(\mathrm{Sb})$ (controls), micro-arc oxidation (MAO) and glow discharge plasma (GDP) (experimental groups). Surfaces were characterized using scanning electron microscopy $(\mathrm{SEM})(\mathrm{n}=1)$, energy dispersive spec- troscopy (EDS) $(n=1), X$-ray diffraction (XRD) $(n=1)$, atomic force microscopy $(A F M)(n=1)$, perfilometry $(n=10)$, wettability and surface free energy $(\mathrm{n}=10)$. For biofilm assay, a three-species biofilm composed by S. sanguinis, A. naeslundii and F. nucleatum was developed onto the cpTi discs for $16.5 \mathrm{~h}$ (early biofilm) and $64.5 \mathrm{~h}$ (mature biofilm) in a modified fluid universal medium (mFUM) with $0.15 \%$ glucose and $0.15 \%$ sucrose containing $60 \%$ human saliva and $10 \%$ horse serum. The number of colony forming units and the extracellular matrix composition (proteins and carbohydrates) were determined $(\mathrm{n}=12)$. SEM and Confocal laser scanning microscopy (CLSM) were used to visualize biofilm organization $(n=2)$. In order to determine the impact of the experimental $\mathrm{Ti}$ treatments on the biological properties of pre-osteoblasts, MC3T3-E1 were cultured on Ti discs submitted to the experimental conditions, and cell proliferation and morphology assessed by and the methyl thiazol tetrazolium (MTT) assay at days 1,3 and $6(n=3)$ and SEM at days 2 and 4 days $(n=2)$, respectively.

\subsection{CpTi discs preparation}

CpTi discs (Grade II - American Society for Testing of Material) (MacMaster Carr) with $10 \mathrm{~mm}$ in diameter and $2 \mathrm{~mm}$ thickness were ground with \#320, \#400, and \#600 SiC abrasive paper (Carbimet 2, Buehler). The composition in wt\% of cpTi was Ti (99.7), C (0.006), $\mathrm{Fe}(0.12), \mathrm{O}_{2}(0.16), \mathrm{N}_{2 c}(0.004)$, and $\mathrm{H}_{2}$ (0.0019) [30].

In this study, two control groups were used: machined (polished) and sandblasted. The sandblasting procedure followed a previously described protocol [31]. Discs were blasted with $150-\mu \mathrm{m}$ aluminum oxide $\left(\mathrm{Al}_{2} \mathrm{O}_{3}\right)$ particles (Polidental Indústria Comércio Ltd) at a distance of $50 \mathrm{~mm}$, an angle of $90^{\circ}$ and air pressure of $0.45 \mathrm{MPa}$ for $30 \mathrm{~s}$ [31]. Discs were ultrasonically washed with distilled water for $15 \mathrm{~min}$ and allowed to dry at room temperature. Subsequently, the surface of the discs were etched by a mixture of $0.1 \mathrm{~mol} / \mathrm{L}$ of $\mathrm{HCl}$ and $8.8 \mathrm{~mol} / \mathrm{L}$ of $\mathrm{H}_{2} \mathrm{O}_{2}$ at a temperature of $80^{\circ} \mathrm{C}$ for $20 \mathrm{~min}$, then rinsed in distilled water, oven dried at $50^{\circ} \mathrm{C}$ for $12 \mathrm{~h}$

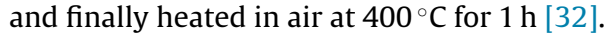

\subsubsection{Surface modification by $M A O$}

The machined discs were washed and degreased with acetone following by rinsing with distilled water for $10 \mathrm{~min}$ each in an ultrasonic bath and then dried in warm air. A DC power supply (Plasma Technology Ltd) was used for MAO process. A stainless steel beaker with re-circulating cooling system that maintained the temperature of the electrolyte at approximately $20^{\circ} \mathrm{C}$ was used as the electrolytic container and cathode while the cpTi discs was placed in the electrolytic cell as the anode. The electrolytic solution was based on $0.3 \mathrm{M}$ of calcium acetate ( $\mathrm{Ca}$ $\left.\left(\mathrm{CH}_{3} \mathrm{CO}_{2}\right)_{2}\right)$ (Sigma-Aldrich) and $0.02 \mathrm{M}$ of glycerophosphate disodium $\left(\mathrm{C}_{3} \mathrm{H}_{7} \mathrm{Na}_{2} \mathrm{O}_{6} \mathrm{P}\right)$ (Sigma-Aldrich). Treatment was carried out for $10 \mathrm{~min}$, voltage $290 \mathrm{~V}$, frequency $250 \mathrm{~Hz}$ and duty cycle $(60 \%)$ [33]. Afterwards, cpTi discs were washed with deionized water and air-dried.

\subsubsection{Surface modification by GDP}

The cpTi discs were ultrasonically washed in distilled water and detergent (Det limp 32, Chemco) for $15 \mathrm{~min}$, rinsed in abundant tap water, degreased with acetone for $15 \mathrm{~min}$ and then air dried. Plasma treatments were performed in a custom-made glass reactor from the Technological Plasma Laboratory (LaPTec; Sao Paulo State University), further described elsewhere [34]. Prior film deposition, discs were cleaned for $600 \mathrm{~s}$ by plasma ablation in an atmosphere composed of $0.5 \times 10^{-2}$ Torr of the argon (50\%) and $\mathrm{H}_{2}$ (50\%) mixture. The system base and working pressure in those experiments were $2 \times 10^{-2}$ and $3 \times 10^{-2}$ Torr, respectively. Subsequently, the plasma deposition was performed during $900 \mathrm{~s}$ in an atmosphere of $70 \%$ of hexamethyldisiloxane (HDMSO), $15 \%$ of $\mathrm{O}_{2}$, and $15 \%$ of argon 
by applying radio frequency (RF) signal of $13.56 \mathrm{MHz}(100 \mathrm{~W})$ at the substrate holder and grounding the top electrode. The background pressure, gas pressure and working gas pressure were maintained at $2 \times 10^{-2}, 1.8 \times 10^{-1}$ and $2 \times 10^{-1}$ Torr, respectively. Then, a final plasma surface treatment was conducted in pure oxygen plasma and without exposing samples to atmosphere. For that, $7.5 \times 10^{-2}$ Torr of oxygen was added to the reactor, producing a working pressure of $9.5 \times 10^{-2}$ Torr. The treatment plasma, which last $300 \mathrm{~s}$, was excited by applying RF signal of $13.56 \mathrm{MHz}(100 \mathrm{~W})$ at the substrate holder while earthening the top electrode. The whole procedure was performed 2 times and in both sides of the discs.

\subsection{Surface characterization}

The morphology of cpTi surfaces was observed with scanning electron microscopy (SEM; JEOL JSM-6010LA, JEOL) and the chemical composition was evaluated by energy dispersive spectroscopy (EDS) using a detector attached to the SEM. Surface micrographs were recorded using secondary electrons detector and beam energy of 5.0 and $10.0 \mathrm{keV}$. Three different regions were selected to perform the EDS analysis. The phase composition of the surfaces was determined by X-ray diffractometer (XRD; X' Pert Powder) using $\mathrm{Cu}-\mathrm{K} \alpha$ radiation $(\lambda=1,540598 \AA$ ) at $45 \mathrm{kV}$ and $40 \mathrm{~mA}$. Three-dimensional images $\left(50 \times 50 \mu \mathrm{m}^{2}\right)$ were taken to observe the topographies and profile of all surfaces using atomic force microscopy (AFM) (5500AFM/SPM, Agilent Technologies). A noncontact mode was used and two distinct areas of the samples were chosen for profile analysis. Gwyddion software was used for image processing. The cpTi surface roughness $(n=10)$ was determined by profilemeter using a Dektak D150; Veeco system. Three line profiles of $500 \mu \mathrm{m}$ in length were taken from different areas during $12 \mathrm{~s}$ on each disc and the average value was calculated. The average, $R_{a}$, root mean-square-average, $R_{q}$, average maximum height of the profile, $R_{z}$, and maximum height, $R_{t}$, roughnesses were derived from the acquired profiles.

The receptivity of the samples to water and diiodomethane $(n=10)$ was evaluated from sessile drop method. Measurements were conducted at room temperature but with controlled humidity in an automatic goniometer (Ramé-Hart 100-00; Ramé-Hart Instrument Co, Succasunna, NJ, USA). With the water (polar component) and diiodomethane (dispersive component) contact angles, the surface free energy was determined. The contact angle was calculated according to the Young equation:

$Y s v=Y s 1+Y 1 v \cos \theta_{c}$

where $\Theta_{c}=$ contact angle, $Y=$ surface energy of solid in equilibrium with vapor (sv), solid in equilibrium with liquid (sl), and liquid in equilibrium with vapor (lv). The relation between contact angle and surface energy was evaluated through the Owens-Wendt method, based on the contact angle of liquids with different polarities [35]. A total of 10 measurements were performed for each disc.

\subsection{Biofilm assay}

Prior to biofilm assay, discs were sterilized by gamma radiation $(14.5 \pm 0.05 \mathrm{kGy})$ [36]. A three-species biofilm composed of $S$. sanguinis IAL 1832, A. naeslundii OMZ 745, and F. nucleatum OMZ 596 was developed on the cpTi discs to evaluate the adhesion of microbial cells and the biofilm formed. The biofilm were grown on discs in 24-wells cell culture plates supplemented with whole saliva and blood serum in order to mimic a peri-implantitis condition [37].

\subsubsection{Biofilm development}

For the inoculum preparation, the microorganisms were individually cultivated on Columbia blood agar (Difco Laboratories) supplemented with $5 \%$ defibrinated sheep blood (CBA), and then in fluid universal medium containing $0.15 \%$ glucose and 0.15 \% sucrose [38] supplemented with $67 \mathrm{mmol} / \mathrm{L}$ Sorensen's buffer, pH 7.2 ("modified fluid universal medium", mFUM) in anaerobic atmosphere $\left(10 \% \mathrm{H}_{2}, 10 \% \mathrm{CO}_{2}\right.$ e $\left.80 \% \mathrm{~N}_{2}\right)$ at $37^{\circ} \mathrm{C}$ [39]. The final culture of each microorganism was independently adjusted to $\mathrm{OD}_{550} 1.0 \pm 0.05$ [40]. The three-species inoculum was prepared by mixing equal volumes of each density-adjusted culture. Prior to the biofilm assay, a protein pellicle was formed on cpTi. The whole unstimulated saliva was collected and donated from four healthy volunteers who provided their consent and signature (register number 030/2014). Saliva volumes were pooled, centrifuged and the supernate was pasteurized and stored in polypropylene at $-20^{\circ} \mathrm{C}$ as describe by Guggenheim et al. [40] until the onset of the biofilm assay. Discs were pre-incubated in 24-well culture plate with a mixture of $85 \%$ unstimulated human whole saliva and $15 \%$ horse serum at $37^{\circ} \mathrm{C}$ for $4 \mathrm{~h}$. The protein-coated discs were transferred to wells containing $0.2 \mathrm{~mL}$ of mixed-species inoculum and $1.8 \mathrm{~mL}$ of mFUM $0.3 \%$ glucose containing proportion of $30 \% \mathrm{mFUM}$, $60 \%$ saliva and $10 \%$ horse serum (3:6:1). The plates were incubated anaerobically at $37^{\circ} \mathrm{C}$ for $16.5 \mathrm{~h}$ and $64.5 \mathrm{~h}$. From $16.5 \mathrm{~h}$ to $64.5 \mathrm{~h}$, the biofilms were dipped in $0.9 \% \mathrm{NaCl}$ solution three times a day to remove non-adherent cells. The medium was changed at 16.5 and $40.5 \mathrm{~h}$ for a fresh mixture of mFUM $0.15 \%$ glucose and $0.15 \%$ sucrose, saliva and serum (3:6:1), to encourage the biofilm growth, removing the old medium with dead cells and not adhered to the biofilm that may interfere with biofilm development. All assays were performed independently at least 3 times in quadruplicate $(n=12)$.

\subsubsection{Biofilm analysis}

Discs were transferred to cryogenic tubes containing $3 \mathrm{~mL}$ of $0.9 \% \mathrm{NaCl}$ solution and sonicated at $7 \mathrm{~W}$ for $30 \mathrm{~s}$ (Sonifier ${ }^{\circledR}$, Branson Ultrasonics Corporation) [41]. The resultant suspension was used for biofilm analysis. For quantification of the colony forming units (CFU), $0.1 \mathrm{~mL}$ aliquot of the suspension was serially diluted in saline solution and plated in the following culture media: CBA (Difco Laboratories) supplemented with $5 \%$ defibrinated sheep blood for total microorganism count and CBA plus norfloxacin ( $1 \mathrm{mg} / \mathrm{L})$, erythromycin $(1 \mathrm{mg} / \mathrm{L})$, and vancomycin $(4 \mathrm{mg} / \mathrm{L})$ for $F$. nucleatum; Mitis Salivarius Agar (Difco Laboratories) for S. sanguinis; Cadmium Sulfate Fluoride Acridine Trypticase Agar (Difco Laboratories) for $A$. naeslundii. CBA and CBA Plus plates were incubated anaerobically for $72 \mathrm{~h}$ at $37^{\circ} \mathrm{C}$, while CFAT and MSA plates were incubated in an atmosphere of $10 \% \mathrm{CO}_{2}$ for $48 \mathrm{~h}$ at $37^{\circ} \mathrm{C}$. After obtaining the counts, data were expressed as colony forming units per $\mathrm{mL}\left(\log _{10} \mathrm{CFU} / \mathrm{mL}\right)$ [42].

The protein content of the pellicle (prior to biofilm assay) (negative control) and the biofilm was determined using the bicinchoninic acid technique (BCA Kit, Sigma-Aldrich). Bovine serum albumin was used as standard [43]. A total of $150 \mu \mathrm{L}$ of the sonicated suspension was placed into 96-well cell culture plates containing $150 \mu \mathrm{L}$ of the mixture of BCA Kit reagents. The plate was incubated at $60^{\circ} \mathrm{C}$ for $60 \mathrm{~min}$ and the absorbance determined at $562 \mathrm{~nm}$. The carbohydrate content of pellicle (prior to biofilm assay) (negative control) and biofilm was determined by the phenolsulfuric method [44], using glucose as standard. A volume of $400 \mu \mathrm{L}$ of the sonicated suspension was used to extract soluble and insoluble extracellular polysaccharides as described by Aires et al. [41]. The extracellular polysaccharides amount was calculated by the sum of soluble and insoluble extracellular polysaccharides. Protein and polysaccharide amounts present in the pellicle and biofilm was normalized by $\log _{10}$ CFU. Data were expressed as fold over negative control for each surface type.

The biofilm organization was examined by SEM $(n=2)$. Biofilms on discs were fixed for $2 \mathrm{~h}$ in Karnovsky's Fixative solution $(2.5 \%$ 
glutaraldehyde, $2 \%$ formaldehyde, $0.1 \mathrm{M}$ sodium phosphate buffer; $\mathrm{pH}$ 7.2), followed by dehydration in a series of ethanol washes. The discs were then allowed to dry aseptically. The discs were mounted on stubs, sputter-coated with gold and examined with a SEM (JEOL JSM-5600LV, JEOL) at $15 \mathrm{kV}$ [45].

The biofilm structure was visualized by CLSM $(n=2)$. The biofilms were submitted to fluorescence in vitro hybridization (FISH) with rRNA-specific oligonucleotide probes (Invitrogen, Carlsbad, USA) for total biofilm (EUB 388-Alexa Fluor 488), F. nucleatum (FUS664- Alexa Fluor 647), and A. naeslundii (ANA103-Alexa Fluor 532) [46]. Each disc, covered with biofilm, was incubated in hybridization buffer (0.9 M NaCl, $20 \mathrm{mM}$ Tris- $\mathrm{HCl}$ ( $\mathrm{pH} 7.5$ ), 30\% formamide, and $0.01 \%$ SDS) with rRNA-specific probes at $5 \mu \mathrm{g} / \mathrm{mL}$ for $180 \mathrm{~min}$ at $46^{\circ} \mathrm{C}$. Then, the biofilm was incubated in washing buffer (20 mM Tris- $\mathrm{HCl}$ (pH 7.5), $5 \mathrm{mM}$ EDTA, $112 \mathrm{mM} \mathrm{NaCl}$, and 0.01\% SDS) for $15 \mathrm{~min}$ at $48^{\circ} \mathrm{C}$, and embedded upside-down in $10 \mu \mathrm{L}$ of Mowiol on a coverslip. The biofilms were evaluated with a DMI 6000 CS inverted microscope (Leica Microsystems CMS, Mannheim, Germany) coupled to TCS SP5 computer-operated CLSM system (Leica Microsystems CMS, Mannheim, Germany) [46].

\subsection{Biological assay}

\subsubsection{Cell culture}

MC3T3-E1 cells were cultured in Minimum Essential Medium Eagle - Alpha Modification (Alpha MEM: Gibco, Life Technologies) supplemented with $10 \%$ fetal bovine serum (FBS) (Gibco, Life Technologies), penicillin $(100 \mathrm{U} / \mathrm{mL})$, and streptomycin $(100 \mathrm{mg} / \mathrm{mL}$ : Gibco, Life Technologies) in a humidified incubator at $37^{\circ} \mathrm{C}$ and $5 \%$ $\mathrm{CO}_{2}$ atmosphere. To determine the impact of Ti treatment on cell proliferation, MC3T3-E1 cells were seeded at $3 \times 10^{4}$ cells $/$ well in a 24-well plates (Corning Costar). After $24 \mathrm{~h}$, medium was replaced for Alpha MEM supplemented with 2\% FBS plus antibiotics (day 0), which was replaced every other day until the end of the experimental period. Proliferation rate was determined by the MTT assay at 1 , 3 , and 6 days. The MTT assay was performed following the manufacturer's instructions. Briefly, medium was aspirated and replaced by $900 \mu \mathrm{L}$ of Alpha MEM added with $100 \mu \mathrm{L}$ of MTT $(5 \mathrm{mg} / \mathrm{mL}$ ) (Life Technologies) at $37^{\circ} \mathrm{C}$, and $5 \% \mathrm{CO}_{2}$ and incubated for $4 \mathrm{~h}$, protected from light. The supernatant in each well was gently extracted and replaced with $2000 \mu \mathrm{L}$ of absolute alcohol (Sigma-Aldrich). After dissolution of formazan crystals, optical density of the solution was read at $570 \mathrm{~nm}$ wave-length using an Elisa Reader (VersaMax, Molecular Devices). Experiments were performed in triplicate and the mean values of the three different readings were considered for statistics. In order to determine the effect of the experimental Ti surfaces on cell morphology, MC3T3-E1 cells were plated in duplicate at $2 \times 10^{4}$ cells $/ \mathrm{mL}$ in 24-well culture plates in Alpha MEM supplemented with $10 \%$ FBS and antibiotics, for $24 \mathrm{~h}$ to allow cell adhesion on the discs. Then, medium was replaced for Alpha MEM supplemented with 2\% FBS plus antibiotics (day 0), which was replaced every other day until the end of the experimental period. Cell morphology was verified by SEM analysis at days 2 and 4. Briefly, culture medium was aspirated and the cells were fixed with Karnovsky's solution ( $\mathrm{pH} 7.4$ ) overnight at $4{ }^{\circ} \mathrm{C}$ and post-fixed in $1 \%$ osmium tetraoxide in distilled water for $1 \mathrm{~h}$ at room temperature. Then, they were dehydrated through a graded ethanol series (35\%, 50\%, 70\%, 90\%, and 100\%) at room temperature for $10 \mathrm{~min}$ each. Finally, samples were critical-point dried (Denton Vacuum, mod. DCP-1) and gold sputtered (Bal-Tec, mod. SCD 050).

\subsection{Statistical analysis}

One-way ANOVA was used to test the effect of different surface treatments (4 levels) on the surface roughness ( $R a, R q, R t, R z$ ), wettability, surface free energy, number of colony forming units, and protein and carbohydrate contents. Two-way ANOVA was used to evaluate the effect of surface treatments (4 levels) and time ( 3 levels) on cell proliferation. Means were compared with the Tukey Honestly Significant Difference (HSD) test. All tests were conducted with a 5\% significance level (SPSS v. 20.0; SPSS Inc).

\section{Results and discussion}

Different surface treatments have been proposed with the aim of improving the biological response of dental implants $[47,48]$. The chemical composition, topography and wettability of the treated cpTi surface are directly related to the process of osseointegration and adherence of microorganisms [49-51]. These properties may determine whether cpTi implants are successfully incorporated in living organisms and perform their intended function [52]. The chemical changes in the surface of treated cpTi implants may come in contact with the body after the installation of the implant, improving the interaction between the surface and the biological environment [47].

\subsection{Surface characterization}

The SEM (Fig. 1a) micrographs and AFM (Fig. 1b) images show the surface microstructure of the cpTi for controls and experimental groups. M and GDP groups exhibited smooth and uniform surfaces with longitudinal grooves as a result of the polishing procedure. $\mathrm{Sb}$ group showed the formation of crystal-like structures with prominent peaks and deep valleys (asterisk), while in surface treated with MAO the presence of pores similar to volcanoes (arrow) was observed. These results are in agreement with other studies $[33,49]$.

The chemical composition of the cpTi surfaces was analyzed by EDS (Figs. 1c). M group showed peaks of oxygen (O), carbon (C) and titanium (Ti), which may be related to the formation of titanium dioxide $\left(\mathrm{TiO}_{2}\right)$ film. The presence of $\mathrm{C}$ is due to the atmospheric adsorption during disc manipulation and has been considered an inevitable contamination [53]. Its presence has also been correlated with the ketones dissolvent used during fabrication process [54]. Peak of aluminum ( $\mathrm{Al}$ ) was noted in the $\mathrm{Sb}$ group as a result of blasting process with $\mathrm{Al}_{2} \mathrm{O}_{3}$ particles. The acid etching after blasting process tends to increase the bioactivity of Ti material by attracting calcium ions to the surface, which provides better osseointegration process [55]. The $\mathrm{Al}_{2} \mathrm{O}_{3}$ layer and the increased content of $\mathrm{C}$ in this group shadow the underneath layer of $\mathrm{TiO}_{2}$ which may explain the reduced content of Ti when compared to the M group. The presence of sodium ( $\mathrm{Na}$ ) as a contaminant needs further investigation.

Incorporation of calcium (Ca) and phosphorus $(\mathrm{P})$ was noted on the oxide layer of the MAO-treated group. The $\mathrm{Ca} / \mathrm{P}$ ratio was close to the hydroxyapatite (1.67), an effective component for bone growth $[33,48,56]$. In the GDP treated sample it is verified the presence of $30 \%$ of silicon $(\mathrm{Si}), 30 \%$ of oxygen $(\mathrm{O})$ and $40 \%$ of carbon (C), elements characteristic of the organosilicon precursor, HMDSO, $\left(\left(\mathrm{CH}_{3}\right)_{3}-\mathrm{Si}-\mathrm{O}-\mathrm{Si}-\left(\mathrm{CH}_{3}\right)_{3}\right)$ used during plasma polymerization [50]. The high $\mathrm{C}$ proportion (40\%) indicates the formation of an organosilicon structure similar to that found in conventional silicone $(50 \% \mathrm{C}$, $25 \% \mathrm{Si}$ and $25 \% \mathrm{O}_{2}$ ) [57]. The absence of Ti peak in the spectrum of this sample indicates that the organosilicon film has thickness higher than the average penetration depth of the beam eletrons used for the EDS inpections.

In the XRD analysis (Fig. 2), all groups exhibited amorphous phase, excepted MAO group where peaks of anatase and rutile were noted. The reaction between hydroxyl ions $\left(\mathrm{OH}^{-}\right)$and Ti ions $\left(\mathrm{Ti}^{4+}\right)$ are able to form anatase and rutile $\left(\mathrm{TiO}_{2}\right)$ phases in the microdischarge channels [58]. Such crytalline structures are beneficial for enhancing the nucleation and subsequent precipitation of hydroxyapatite, which may increase the bioactivity of the Ti surface [59]. 
a)
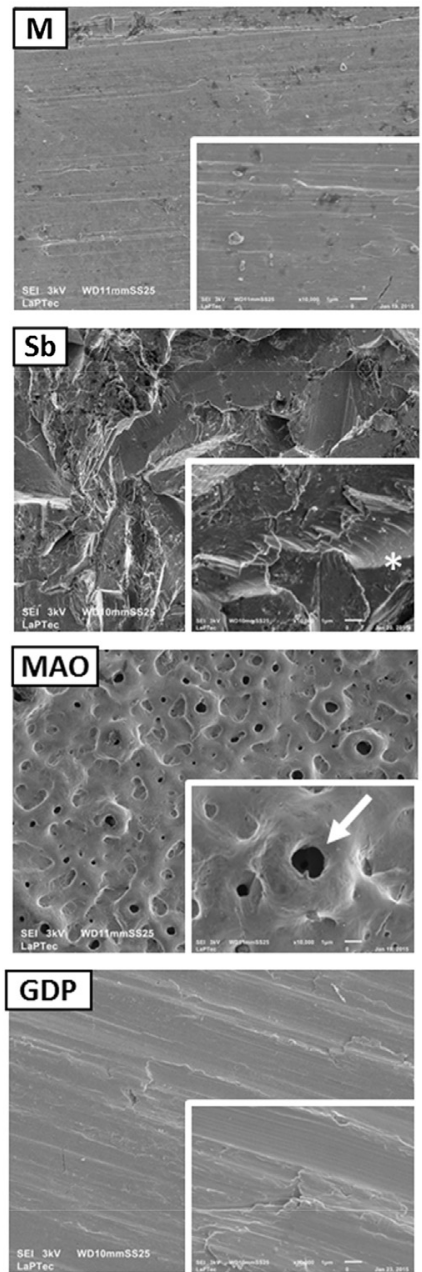

b)
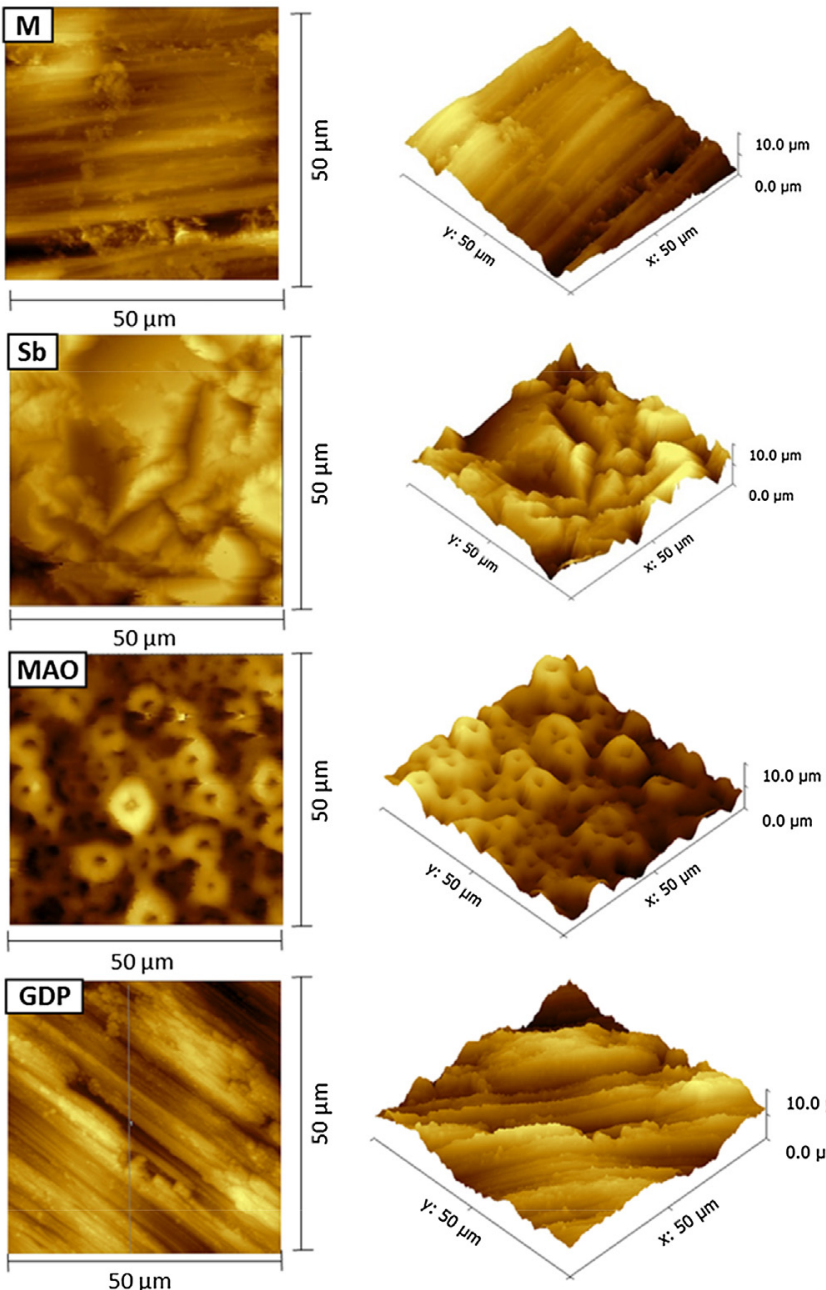
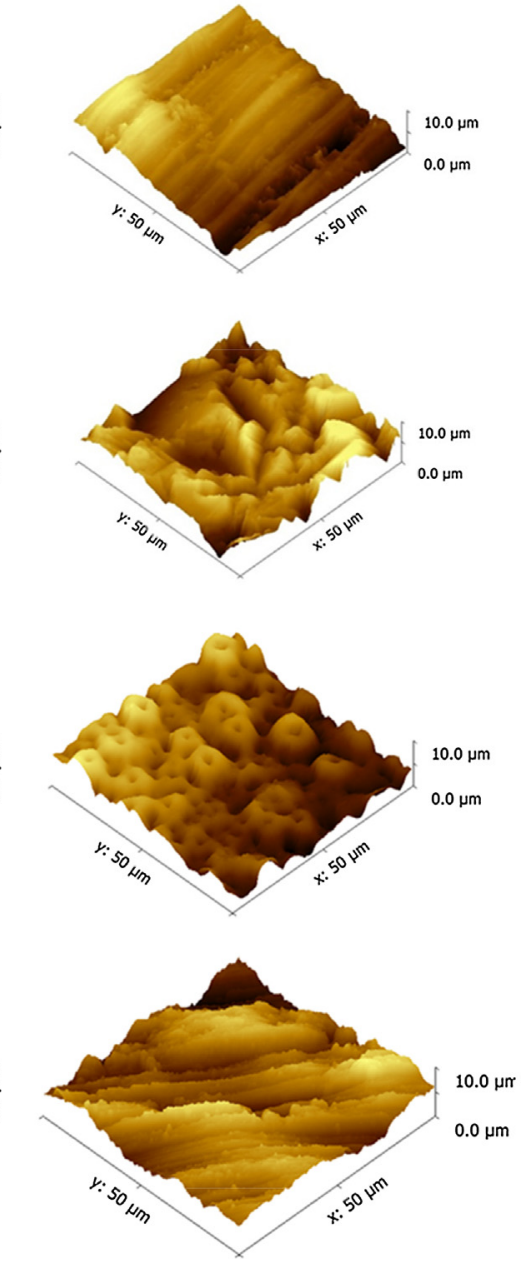

c)

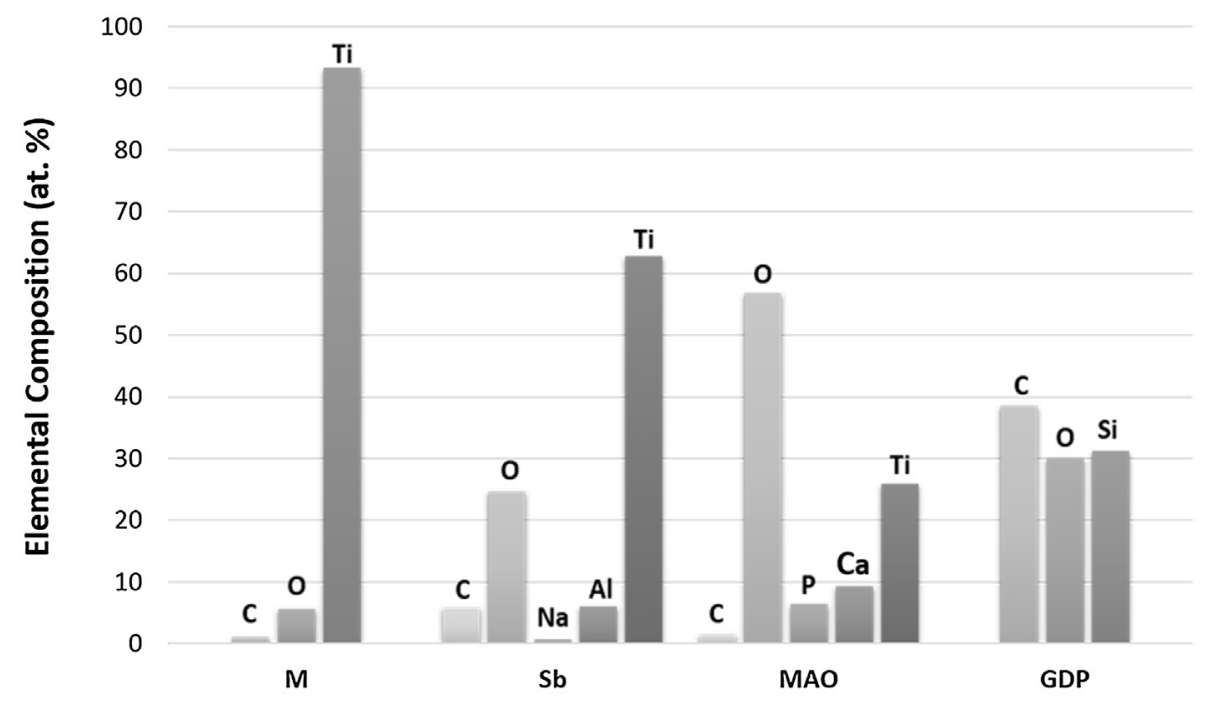

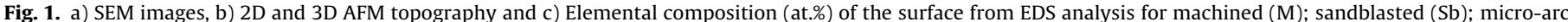
oxidation (MAO); and glow discharge plasma (GDP) groups.

Various surface parameters were used to quantify the surface roughness of $\mathrm{cp}$-Ti, including $\mathrm{Ra}, \mathrm{Rq}, \mathrm{Rz}$ and $\mathrm{Rt}$. Ra is widely used for the evaluation of the surface, and it serves as general guideline on the surface texture; $\mathrm{Rq}$ is a quadratic roughess average; $\mathrm{Rz}$ reflects outlying points because it averages only five highest peaks and five deepest valleys; Rt is the vertical distance between the highest peak and the deepest valley in the evaluation lenghth [60]

The roughness patterns were slightly higher for the $\mathrm{Sb}$ and MAO groups when compared to machined and GDP groups $(p<0.05)$ (Fig. 3). According to a recent study, the incorporation of calcium as well as $\mathrm{Al}_{2} \mathrm{O}_{3}$ particles can produce rough surfaces [33]. It has 


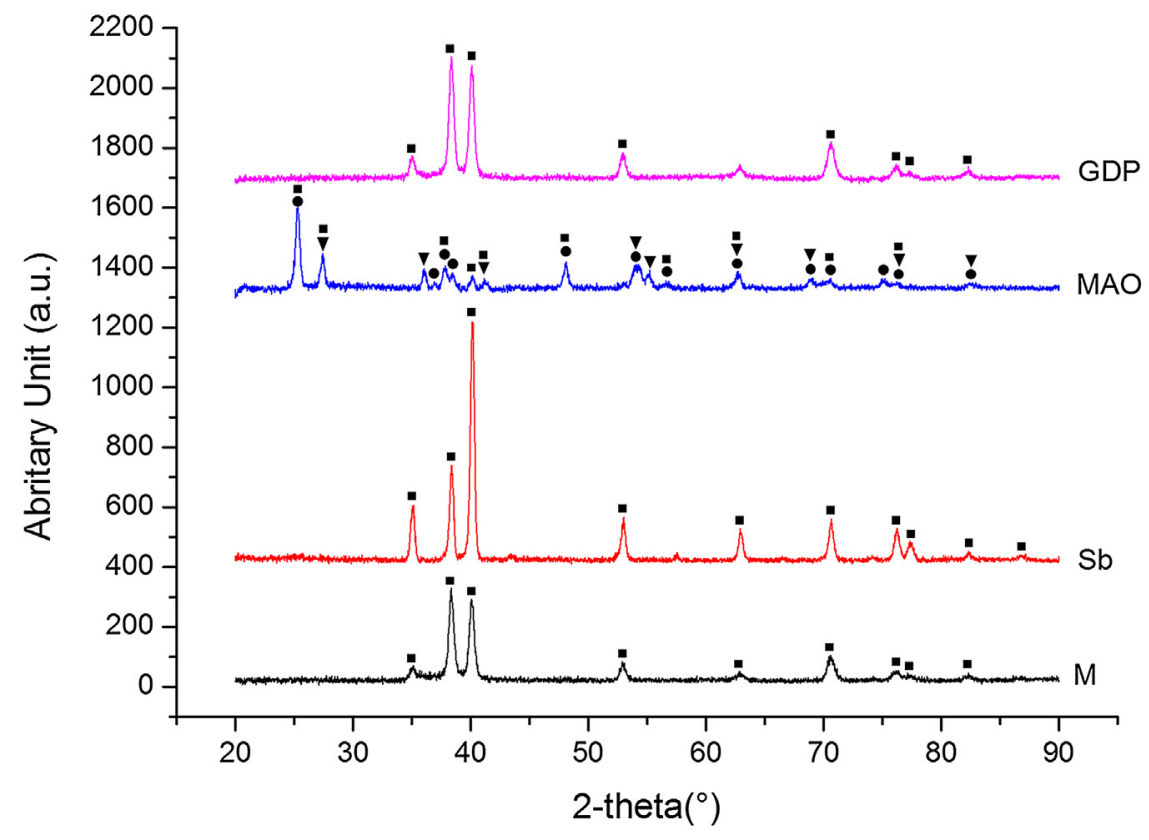

Fig. 2. XRD pattern obtained from all studied groups, $\boldsymbol{\square}$ Ti; $\bullet$ Rutile; $\mathbf{\nabla}$ Anatase.

\section{5}

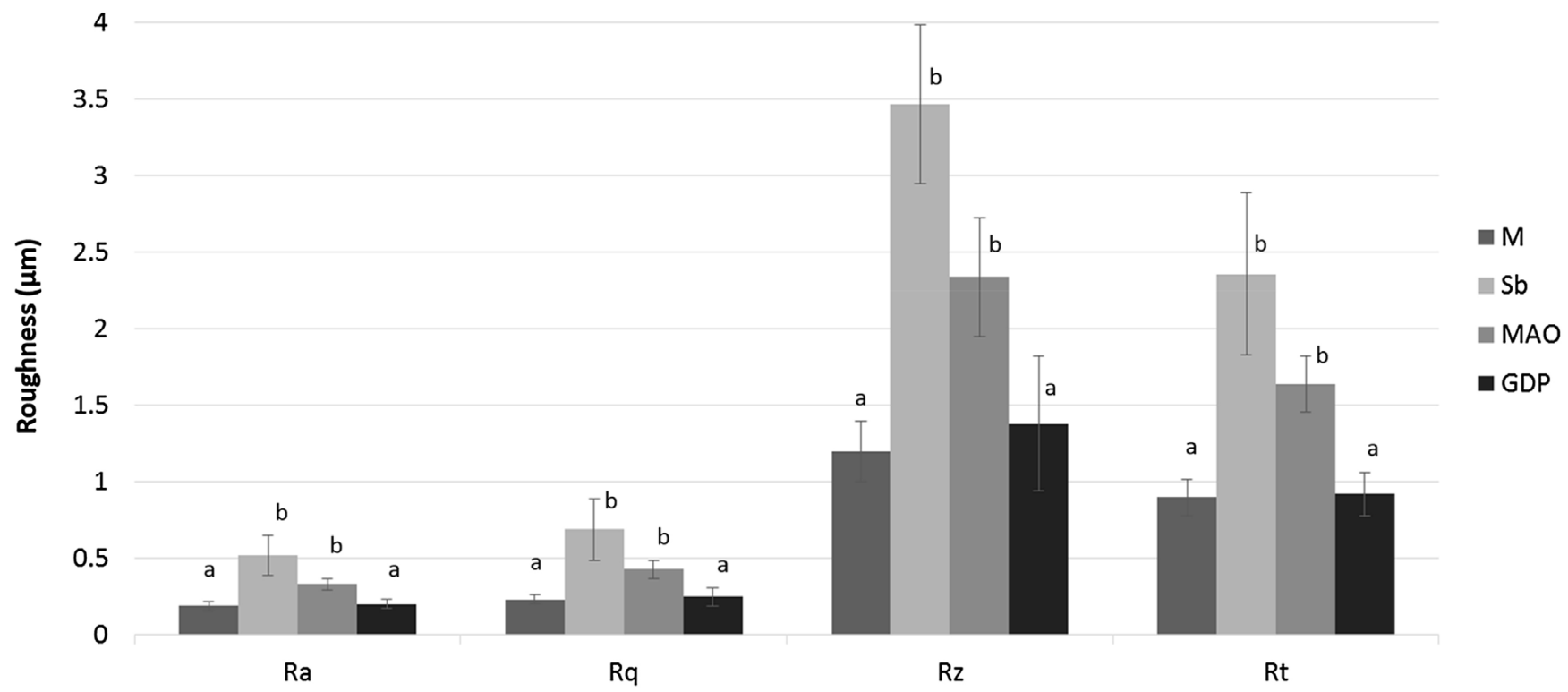

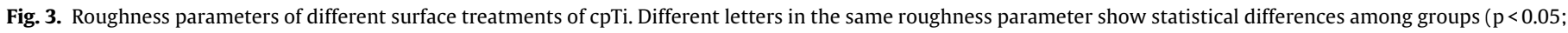
Tukey HSD test).

been suggested that the bond strength between the implant and the surrounding bone tissue depends mainly on the bone contact area. Thus the pattern and roughness of the implant may have a direct effect on the stability of the anchoring in relative smooth surfaces, enhancing the advantage of these coatings on metallic substrates $[25,59,61]$.

The surface properties of a material may depend on the type of surface treatment, which can produce different textures, wetting and surface energy values [62]. In this study, reduced water contact angle (i.e. greater wettability) $(p<0.05)$ was noted for all treated groups, where the GPD group exhbited the lowest one (Fig. 4). As a consequence, the surface free energy of GDP treated group was the highest $(\mathrm{p}<0.05)$. According to the EDS results (Fig. 1c), the GDP treatment resulted in a organosilicon film $\left(\mathrm{SiO}_{\mathrm{x}} \mathrm{C}_{\mathrm{y}} \mathrm{H}_{\mathrm{z}}\right)$ which is essentially hydrophobic [50,57]. However, the post-deposition treatement in $\mathrm{O}_{2}$ plasma, removes $\mathrm{C}$ from the organosilicon surface converting it into a $\mathrm{SiO}_{\mathrm{x}}$ rich surface [63], while keeping the organosilicon nature of the underneath. Furthermore, $\mathrm{O}_{2}$ gas produces active peroxide radicals under the action of plasmas which promotes the bonding of $\mathrm{C}$ with $\mathrm{O}$ and $\mathrm{OH}^{-}$ions [64], which plays a role in increasing the surface free energy [29]. Increased wettability and surface free energy are favorable for biocompatibility and 
a)

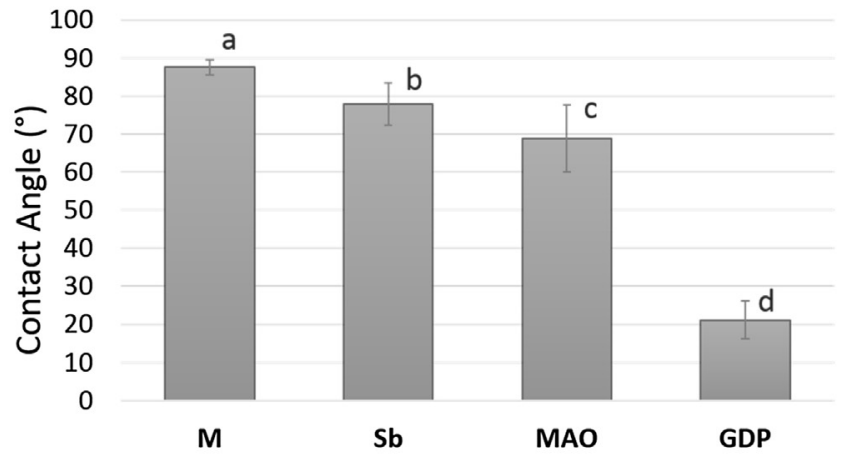

b)

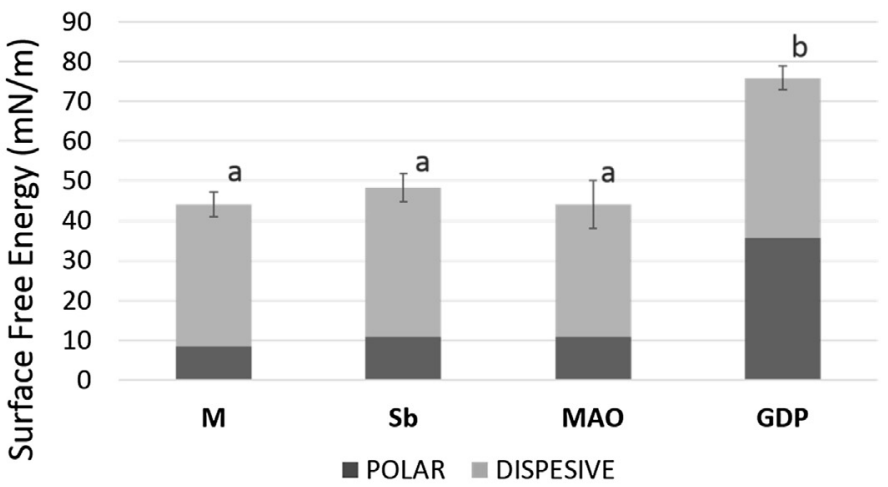

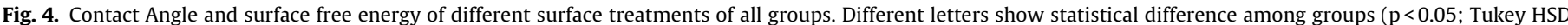
test).

a) $16.5 \mathrm{~h}$

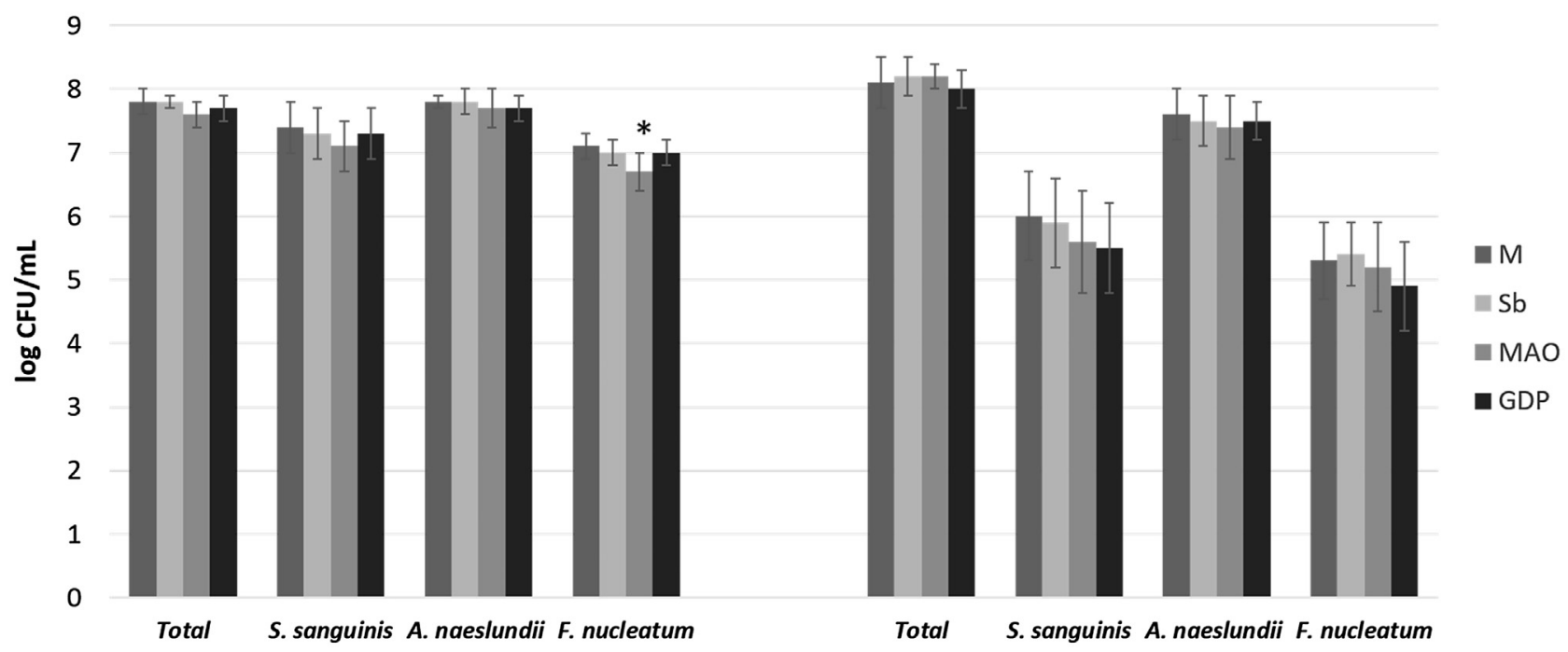

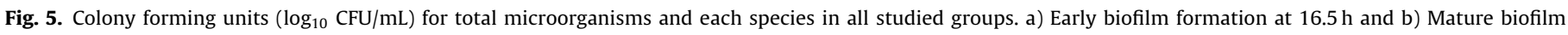
formation at $64.5 \mathrm{~h} .{ }^{*}$ indicates significant difference for F. nucleatum for MAO group ( $\mathrm{p}=0.001$, Tukey HSD test).

cell surface interactions of the substrate with the biological enviroment $[65,66]$, and favor differentiation and deposition of bone matrix $[51,67]$. The structural $\mathrm{SiO}_{x} \mathrm{C}_{y} \mathrm{H}_{z}$ to $\mathrm{SiO}_{\mathrm{x}}$ transformation is also interesting if one considers that $\mathrm{SiO}_{\mathrm{x}}$ present higher hardness, chemical stability and corrosion resistance than the organosilicon structure.

\subsection{Microbiological assay}

\subsubsection{Colony forming units}

Biofilm formation in colony forming units of total microorganisms and S. sanguinis, A. naeslundii e F. nucleatum species at $16.5 \mathrm{~h}$ and $64.5 \mathrm{~h}$ are observed in Fig. 5. The type of surface treatment did not influence the biofilm formation onto cpTi ( $>>0.05$, ANOVA); excepted for F. nucleatum, where MAO exhibited the lowest counts of such microorganism at $16.5 \mathrm{~h}(\mathrm{p}=0.001)$.

A previous study showed that crystalline rich $\mathrm{TiO}_{2}$ layer presented reduction of microorganism adhesion [68]. Therefore the presence of anatase in the cpTi surface may be the driven force toward reduction of $F$. nucleatum adhesion in the MAO group. How- ever, such trend was not observed for mature biofilm, corroborating with previous studies that evaluated the development of other microorganisms in MAO-treated surfaces [69,70]. We believe that the catalytic effect of anatase in the MAO group interfered with $F$. nucleatum growth in the early biofilm; however during the biofilm development, the growth with the other two species might have protected the bacterium against the catalytic effect. In addition, the extracellular matrix may also play a role on the F. bacterium protection against the surface. Such issue deserves further investigation to determine the influence of biofilm matrix on the catalysis of anatase. Contradicting our results, Almaguer-Flores et al. [71] noted that the adhesion of Escherichia coli and Staphylococcus aureus was slightly lower on the amorphous phases compared to their crystalline (i.e. rutile and anatase) counterpart of Ti material. Authors explained that the predominant acidic nature of crystalline surface displays positive charge sites that may electrostatically interact with the net negative charge of the bacterial wall.

Another driven force toward similar CFU counts among cpTi surfaces is the acquired pellicle. Previous studies on poly(methylmethacrylate) [72] and rough $\mathrm{Ti}$ [73] surfaces showed 
a) Proteins

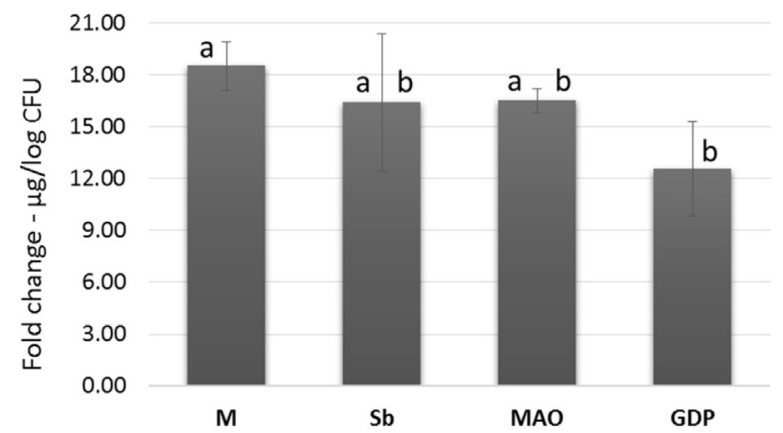

b) Carbohydrate

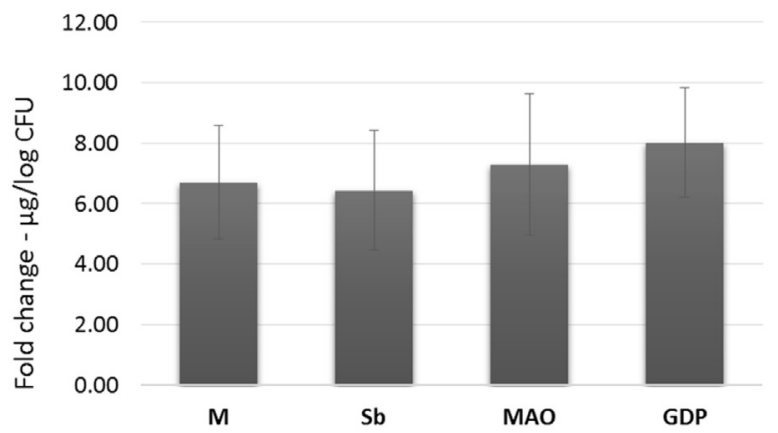

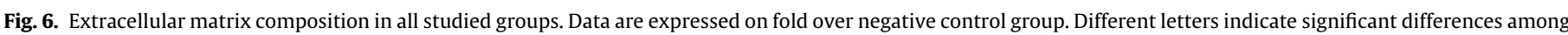
groups ( $\mathrm{p}<0.05$. Tukey HSD test)

that the acquired pellicle increases the surface free energy of such materials. Therefore, this may equalize the differences among the surfaces treatments tested in our study and the interaction between the surface and the biofilm cells became similar among cpTi surface. Further studies investigating the role of saliva + serum pellicle on the surface free energy of coated cpTi are warranted.

The reduction of $F$. nucleatum adhesion in the MAO group is an important finding once such microorganism is associated with periodontitis on this biofilm model and involved in the co-aggregation events that occur during the development and maturation of biofilms; therefore, it may play an important role in the dynamic of early biofilm growth $[74,75]$. However, the same was not observed in mature biofilm. The constant growth with the other two species and the presence of extracellular matrix might have protected $F$. nucleatum against the catalytic effect of anatase in the MAO group.

\subsubsection{Composition of the extracellular matrix}

The extracellular matrix is rich in various components where the proteins and polysaccharides are important for the growth of bacterial biofilm [76]. The quantitative analysis of total proteins and carbohydrates extracted from the three-species biofilm matrices is showed in Fig. 6.

The proteins content was affected by the surface treatment $(p=0.039$, ANOVA). GDP treated samples had lower amounts of protein when compared with M group ( $p=0.027$ ). It has been suggested that lower counts of proteins are related to the electrostatic repulsion and that surfaces of $\mathrm{SiO}_{\mathrm{x}}$ are negatively charged [77]. This may explain the reduction of protein content in the GDP group.

The amount of protein is a factor that is associated with the pathogenicity of the biofilm [78]. Proteins secreted from bacterial biofilms can contribute to the stability of the biofilm, regulating the functions of the host tissue in a manner that is detrimental to the pathogenesis of periodontal disease $[79,80]$. The bacterial species used in this study are associated with periodontitis and peri-implantitis diseases [81,82] and includes early settlers as $S$. sanguinis, secondary colonizers as $A$. naeslundii and late colonizers as $F$. nucleatum. These species were selected for producing the natural dynamics of subgingival biofilm formation in in vitro model $[83,84]$. The F. nucleatum microorganism plays an important role in the development of periodontopathogenic biofilm as it binds with late colonizers (i.e. acting as a bridge between the early colonizers and the late-colonizing pathogen) producing co-aggregation of different species $[85,86]$.

In this study, salivary pellicle was formed onto cpTi surfaces. The pellicle is involved in non-covalent interactions such as electrostatic forces, hydrogen bonding and van der Waals forces, which results in the selective adsorption of salivary proteins [6,87]. This event is important for bacterial colonization by providing binding sites for adherence of microorganisms [88]. Saliva was centrifuged and pasteurized to remove cells, cellular debris and bacterial proteins, reducing the total amount of protein; nevertheless, protein composition is maintained [40]. To simulate the gingival fluid, a medium containing saliva and blood plasma was used. When the blood plasma is in contact with implant surfaces there is a rapid adsorption and the ion plasma proteins forms a protein layer on the surface that is regulated by a dynamic and complex process [87]. Blood plasma feeds the subgingival plaque by exudate crevicular fluid, rich in protein sources, providing nutrients for subgingival bacteria $[89,90]$. In summary, the lack of difference compared to control groups for MAO and the lower content of protein for GDP versus control show that the plasma treated surfaces at least did not increase the biofilm virulence.

The carbohydrates content was not affected by the surface treatment $(p=0.065$, ANOVA). Although it has been reported that the substrate type could influence the carbohydrates production by affecting the microbial metabolism [91], in this study, no difference was found. It is known that $S$. sanguinis and $A$. naeslundii are able to synthesize soluble and insoluble glucans and fructans in the presence of sucrose, respectively $[92,93]$. Once the culture medium used during the experiment had the same concentrations of glucose and sucrose, and all groups had similar CFU for all bacteria species, no difference was expected. Additionally, these data confirm that the plasma treated surfaces were not able to induce a higher extracellular polysaccharide formation, with no increase in biofilm virulence.

\subsubsection{Scanning electron microscopy}

The observation with SEM revealed notable differences in the initial structure of biofilms according to the material surface. After $16.5 \mathrm{~h}$, bacterial population was formed onto the cpTi surfaces (Fig. 7a). Bacterial were arranged either as short streptococcal chains or as multicellular aggregates (asterisk). Fusiform rods, suggestive of $F$. nucleatum or $A$. naeslundii could be recognized inside the biofilms (arrows). The MAO surface exhibited the most concentrated bacterial cells, different from other surfaces that had spread throughout the surfaces of the discs. After $64.5 \mathrm{~h}$, no difference in biofilm architecture was observed among groups (Fig. 7b). The biofilm covered the entire disc surface, channels were noticed and were filled with an amorphous extracellular material, forming a crater-like architecture, mimicking a honeycomb (Fig. 7b).

\subsubsection{Confocal laser scanning microscopy}

The images obtained by CLSM show the three-species biofilms formed on the cpTi surfaces for $64.5 \mathrm{~h}$ (Fig. $7 \mathrm{c}-\mathrm{d}$ ). It was possible 
a) $16.5 \mathrm{~h}$

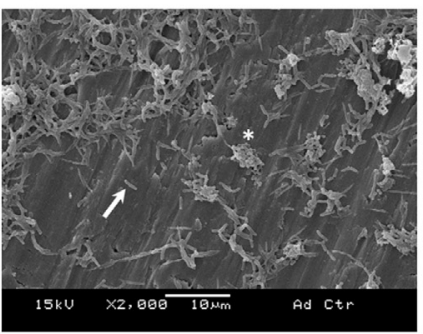

b) $64.5 \mathrm{~h}$

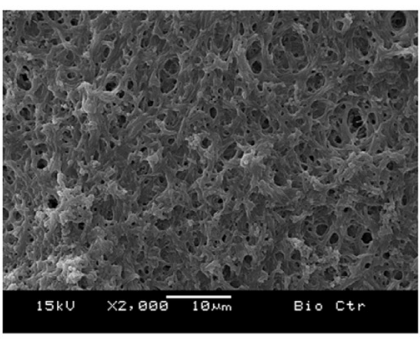

c) $64.5 \mathrm{~h}$

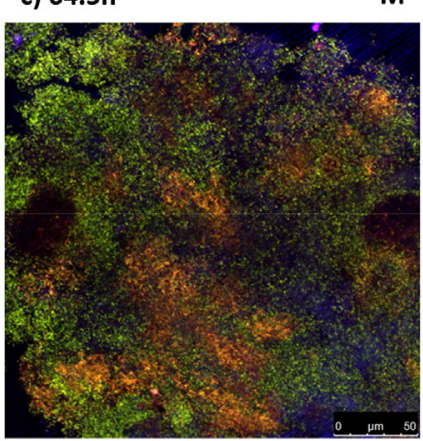

d) $64.5 \mathrm{~h}$

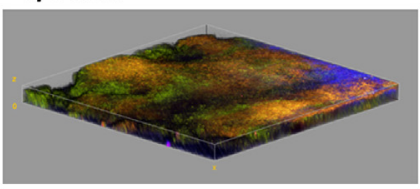

M

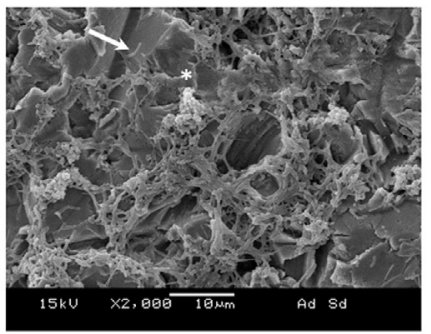

Sb
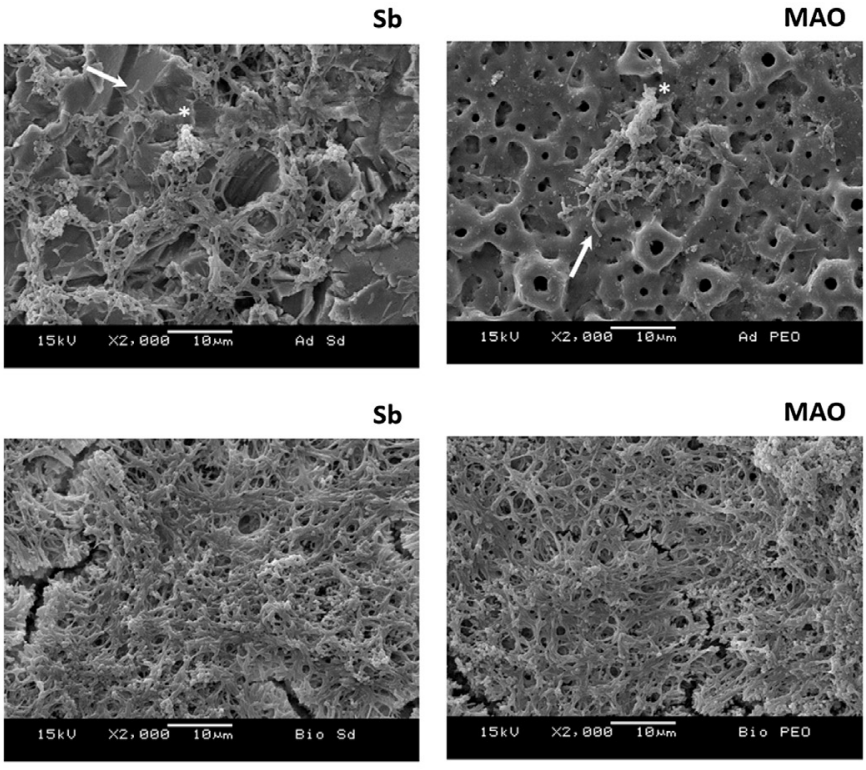

Sb

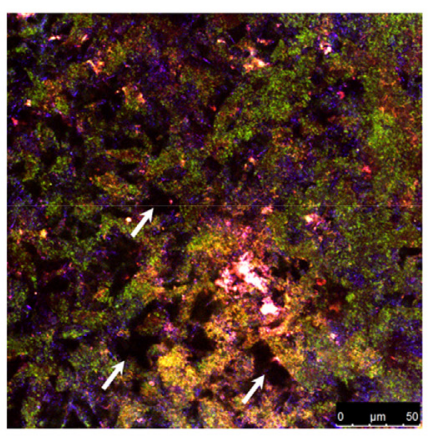

Sb

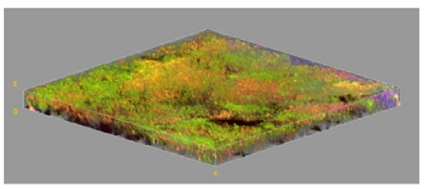

MAO

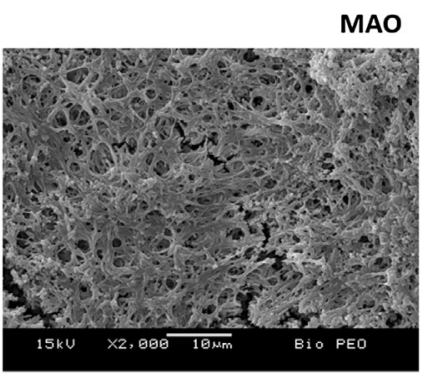

MAO

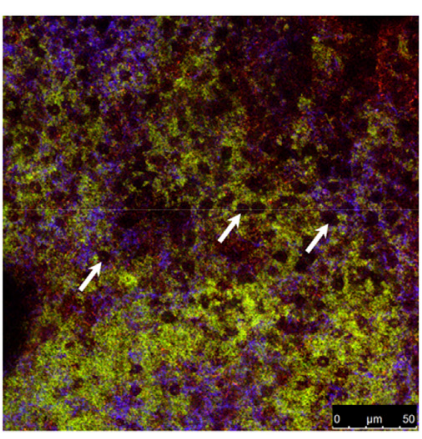

MAO

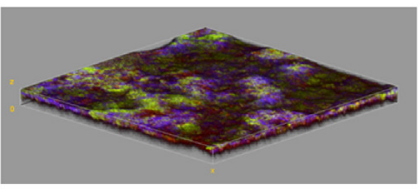

GDP

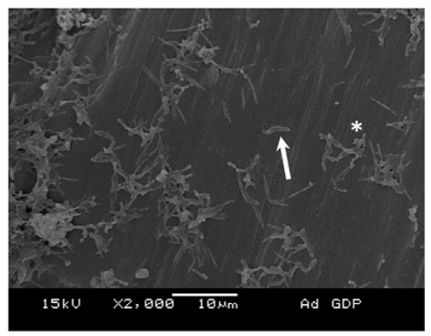

GDP

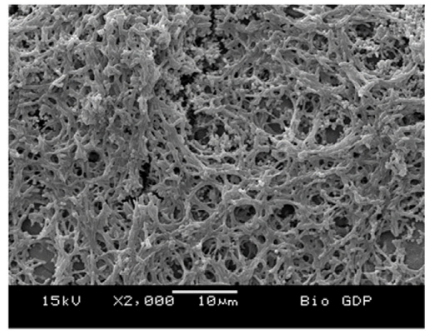

GDP

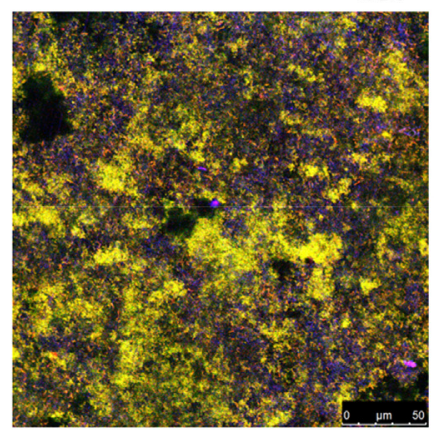

GDP

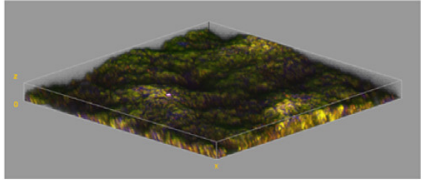

Fig. 7. SEM and CLSM images. Biofilm structure by SEM images in a) early biofilm formation at $16.5 \mathrm{~h}$ and b) mature biofilm formation at $64.5 \mathrm{~h}$. Bacterial biofilms were arranged either as short streptococcal chains or as multicellular aggregates (asterisk). Spindle-shape rods, suggestive of $F$. nucleatum could be recognized inside the biofilms (arrows). CLSM images show (c) z-stack slices of the biofilms next to the treated surfaces: S. sanguinis (green), A. naeslundii (red), and $F$. nucleatum (blue). It is possible to observe black spaces due to the surface treatment: Sb group, irregularities due to the sandblasting procedure (arrows); and MAO group, circular spaces because of the "volcanos" of the MAO treatment (arrows). 3D CLSM images reconstruction (d) of the three-species biofilm developed onto the surfaces after $64.5 \mathrm{~h}$ show a spatial mixture of all the species. (For interpretation of the references to colour in this figure legend, the reader is referred to the web version of this article.)

to observe that all the three species were able to grow together as biofilm. However, it was not possible to visualize an effect of the different surfaces evaluated on the bacterial organization within the biofilms. All the species interacted to each other in all biofilms, and no organization as cluster for any species were observed. The different colors observed in images are due to the rRNA probes used for FISH. A universal probe was used to label all cells in green (mainly S. sanguinis), and specific probes for F. nucleatum (blue) and $A$. naeslundii (red), in order to visualize the species, mainly on the surfaces. When the images were merged, orange and yellowish areas occurred due the staining overlap.

\subsection{Cell culture analysis}

In order to determine the impact of Ti surface treatment on cell biology in vitro, the MTT assay has been extensively used as a standard technique. This method evaluates the capability of viable cells in converting the water-soluble tetrazolium salts to the insoluble formazan crystals via the activity of mitochondrial dehydrogenase enzymes, and allows one to determine the impact of an experimental condition on the proliferation/metabolic rate of the cells $[94,95]$. In the current investigation, cell proliferation was similar among the experimental groups throughout day $3(\mathrm{p}>0.05)$ indicating no cytotoxicity of the plasma surface groups. In contrast, at day 6, cell proliferation was significantly increased for MAO $(\mathrm{p}<0.0001$ ) (Fig. 8a). We speculate that the presence of $\mathrm{Ca}$ and $\mathrm{P}$ may have been the driven force toward such result [96]. In addition, we found that cell proliferation rate was similar between GDP and the control groups throughout the experiment $(p>0.05)$, indicating that plasma treatments may be can be used to modify $\mathrm{Ti}$ implant surfaces with no negative effect on cell biology.

In the present study, we used SEM analysis to determine whether cell morphology was affected by the experimental treatments. In general, it was found that regardless of the experimental 
a)

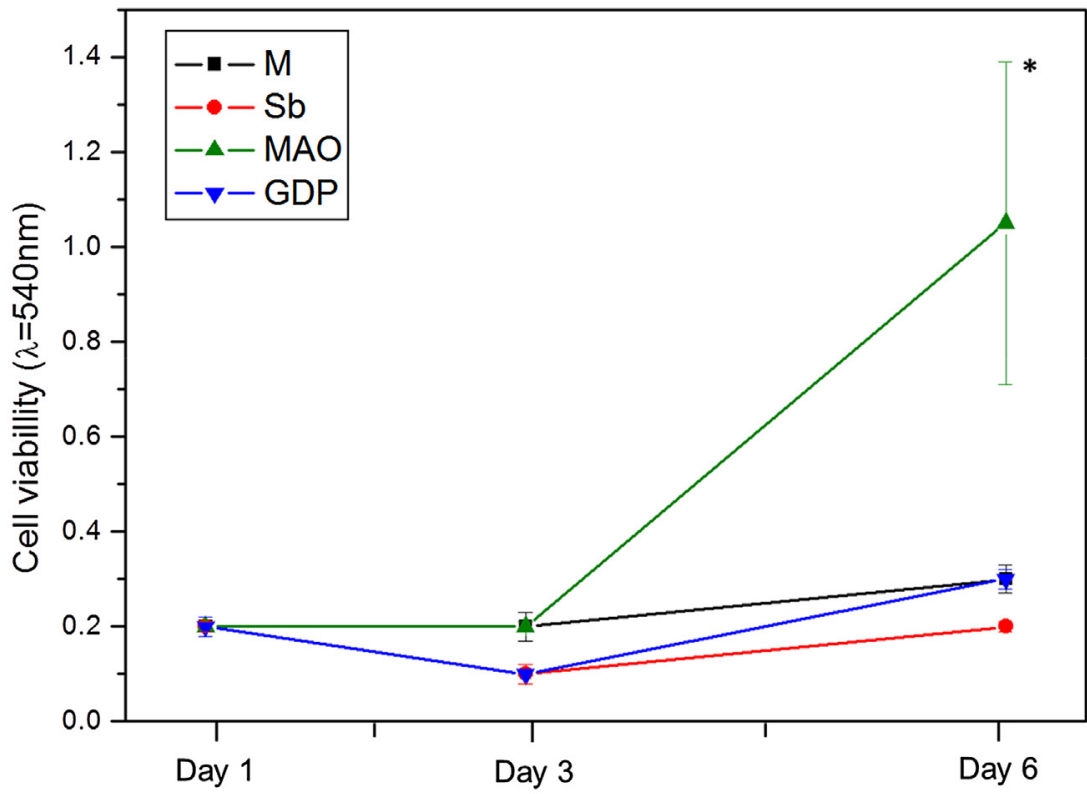

b)

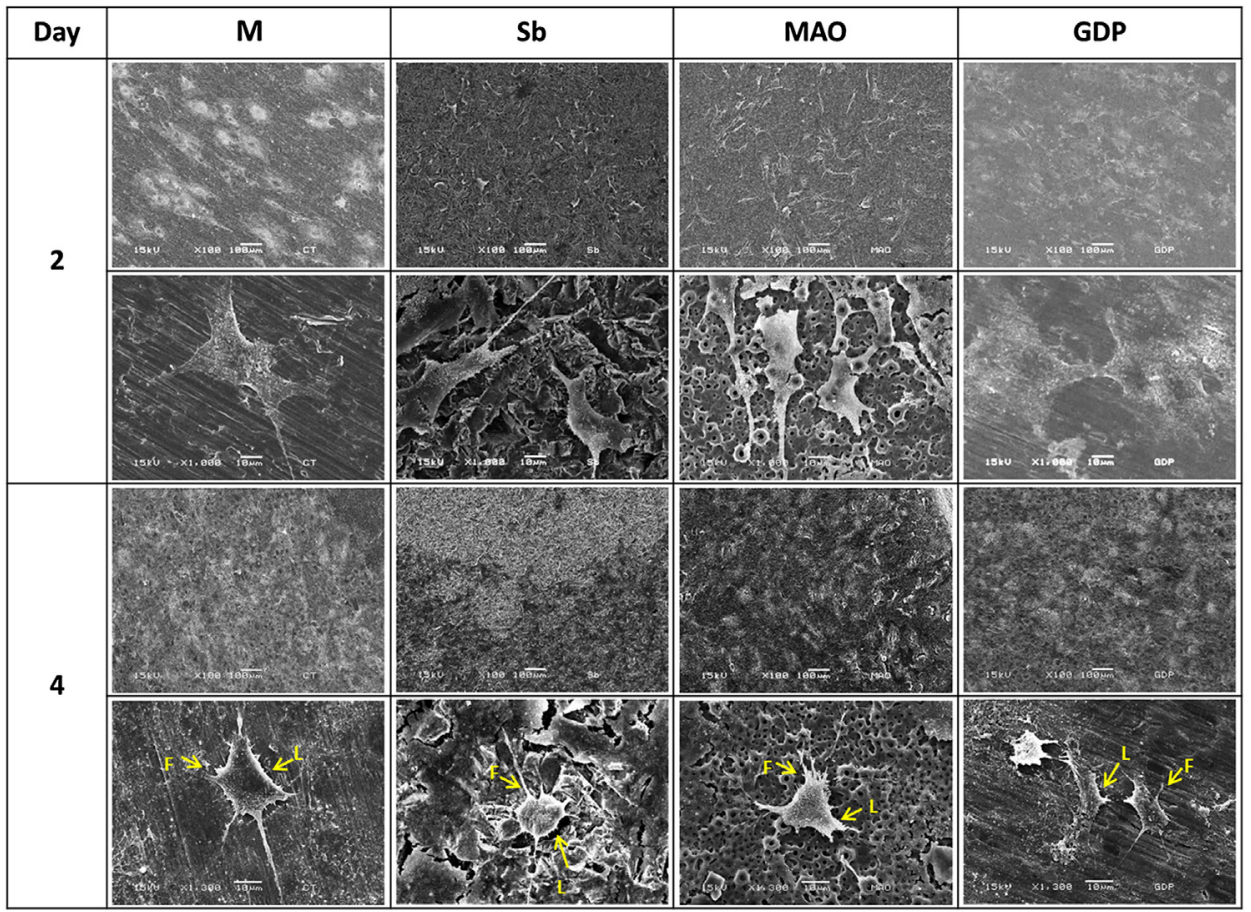

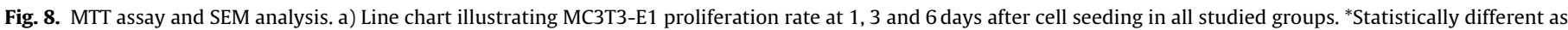

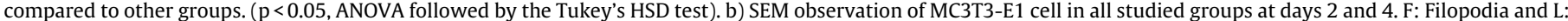
Lamellipodia.

surface, cells were able to adhere to the discs with no relevant differences at day 2 (Fig. 8b). In contrast, at day 4, SEM analysis showed that the MAO surface resulted in a greater cell density as compared to all the other groups leading to wider areas of cell-to-cell contact than other treatments. At higher magnification, well-defined cell with Filopodia (F) spread and grew in the form of thin membranes, exhibited also lamellipodia (L) that are part of the cytoskeleton which involves transport phenomena, traffic and cell division, suggesting a cell response on plasma treated surfaces [97].

\subsection{Clinical implications, limitations and future scope}

The increase in surface roughness can increase the surface area and thereby increasing bacterial colonization [2,6,81]. Surfaces with high surface energy and wettability are also facilitators for enhancing bacterial adhesion $[81,98]$. The most important finding in the current study is that although the MAO treatment promoted greater wettability and roughness than control machined group, no increased bacterial formation was noted. Another interesting 
outcome relies on the GDP surface. Such non-thermal plasma treatment was able to increase the wettability and surface free energy of cpTi while maintaining the levels of biofilm formation as controls. Therefore, such plasma treatments may reduce the osseointegration period while not increasing the peri-implantites risk.

It is difficult to simulate the real in vivo conditions, even using human saliva and horse serum, as this study was carried out under laboratory conditions. Additionally, even though we used a multispecies biofilm to simulate a condition of peri-implantites, such disease is more complex in nature. Other microbe species such as Porphyromonas gingivalis, Campylobacter rectus, Aggregatibacter actinomycetemcomitans, Prevotella nigrescens, Prevotella intermedia and Tannerella forsythia are very common in patients with peri-implantitis. Therefore, further in situ and in vivo studies are warranted to demonstrate the influence of such plasma treatments on the control of oral biofilm formation.

\section{Conclusions}

Following conclusions are drawn from this study

- Plasma treatments increased the wettability of cpTi. GDP treatment enhanced the surface free energy while maintaining the surface roughness properties of cpTi. MAO treatment was able to increase the surface roughness of cpTi and to create anatase and rutile crystalline structures.

- In terms of viable microorganisms cell, surface treatment did not influence the early $(16.5 \mathrm{~h})$ and mature $(64.5 \mathrm{~h})$ biofilm formation onto cpTi, excepted for $F$. nucleatum, where MAO exhibited the lowest counts of such microorganism at $16.5 \mathrm{~h}$.

- The composition of the three-species biofilm extracellular matrix was similar among groups with the exception of GDP that had the lowest content of proteins.

- Experimental treatments did not negatively impact on preosteoblasts biology.

- In a nutshell, the surface treatment of titanium implants with plasma technology is a viable and promising strategy to extend the longevity of dental implants. The treated surface exhibit improved surfaces characteristics while maintaining the bacterial proliferation under control.

\section{Acknowledgments}

The authors would like to thank the State of Sao Paulo Research Foundation (FAPESP) (grant numbers 2013/26145-5 and 2013/08451-1), The Brazilian National Council for Scientific and Technological Development (CNPq) (grant numbers 442786/20140 and 304908/2015-0) and Fundo de Apoio ao Ensino, à Pesquisa e Extensão da UNICAMP (FAEPEX) (grant number 2032/15) for the financial support. The authors also express gratitude to Rafael Parra for his contribution and support in the Plasma Technology Lab at Univ Estadual Paulista (UNESP) and Elton José de Souza from the Department of Physics and Chemistry at UNESP for the AFM facility.

\section{References}

[1] G.N. Belibasakis, Microbiological and immuno-pathological aspects of peri-implant diseases, Arch. Oral Biol. 59 (2014) 66-72.

[2] M. Esposito, J.M. Hirsch, U. Lekholm, et al., Biological factors contributing to failures of osseointegrated oral implants: (I). Success criteria and epidemiology, Eur. J. Oral Sci. 106 (1998) 527-551.

[3] A. Mombelli, R. Gmur, J. Frey, et al., Actinobacillus actinomycetemcomitans and Porphyromonas gingivalis in young Chinese adults, Oral Microbiol. Immunol. 13 (1998) 231-237.

[4] N. Broggini, L.M. McManus, J.S. Hermann, et al., Peri-implant inflammation defined by the implant-abutment interface, J. Dent. Res. 85 (2006) 473-478.
[5] U. Salihoglu, D. Boynuegri, D. Engin, et al., Bacterial adhesion and colonization differences between zirconium oxide and titanium alloys: an in vivo human study, Int. J. Oral Maxillofac. Implants 26 (2011) 101-107.

[6] W. Teughels, N. Van Assche, I. Sliepen, et al., Effect of material characteristics and/or surface topography on biofilm development, Clin. Oral Implants Res. 17 (Suppl. 2) (2006) 68-81.

[7] P.I. Diaz, Microbial diversity and interactions in subgingival biofilm communities, Front. Oral Biol. 15 (2012) 17-40.

[8] C.H. Pereira da Silva, G.M. Vidigal Jr., M. de Uzeda, et al., Influence of titanium surface roughness on attachment of Streptococcus sanguis: an in vitro study, Implant Dent. 14 (2005) 88-93.

[9] J. Li, E.J. Helmerhorst, C.W. Leone, et al., Identification of early microbial colonizers in human dental biofilm, J. Appl. Microbiol. 97 (2004) 1311-1318.

[10] V. Zijnge, M.B. van Leeuwen, J.E. Degener, et al., Oral biofilm architecture on natural teeth, PLoS One 5 (2010) e9321.

[11] P.E. Kolenbrander, R.J. Palmer Jr., S. Periasamy, et al., Oral multispecies biofilm development and the key role of cell-cell distance, Nat. Rev. Microbiol. 8 (2010) 471-480.

[12] V. Frojd, L. Chavez de Paz, M. Andersson, et al., In situ analysis of multispecies biofilm formation on customized titanium surfaces, Mol. Oral Microbiol. 26 (2011) 241-252.

[13] B.J. Paster, S.K. Boches, J.L. Galvin, et al., Bacterial diversity in human subgingival plaque, J. Bacteriol. 183 (2001) 3770-3783.

[14] P.I. Diaz, A. Hoare, B.Y. Hong, Subgingival microbiome shifts and community dynamics in periodontal diseases, J. Calif. Dent. Assoc. 44 (2016) 421-435.

[15] D. Buser, N. Broggini, M. Wieland, et al., Enhanced bone apposition to a chemically modified SLA titanium surface, J. Dent. Res. 83 (2004) 529-533.

[16] D.P. Oliveira, A. Palmieri, F. Carinci, et al., Osteoblasts behavior on chemically treated commercially pure titanium surfaces, J. Biomed. Mater. Res. A 102 (2014) 1816-1822.

[17] I.K. Shim, H.J. Chung, M.R. Jung, et al., Biofunctional porous anodized titanium implants for enhanced bone regeneration, J. Biomed. Mater. Res. A 102 (2014) 3639-3648

[18] Y.T. Sul, C.B. Johansson, S. Petronis, et al., Characteristics of the surface oxides on turned and electrochemically oxidized pure titanium implants up to dielectric breakdown: the oxide thickness, micropore configurations, surface roughness, crystal structure and chemical composition, Biomaterials 23 (2002) 491-501

[19] Y.T. Sul, C. Johansson, A. Wennerberg, et al., Optimum surface properties of oxidized implants for reinforcement of osseointegration: surface chemistry, oxide thickness, porosity, roughness, and crystal structure, Int. J. Oral Maxillofac. Implants 20 (2005) 349-359.

[20] F.C. Walsh, C.T.J. Low, R.J.K. Wood, et al., Plasma electrolytic oxidation (PEO) for production of anodised coatings on lightweight metal (Al, Mg, Ti) alloys, Trans. Inst. Met. Finish. 87 (2009) 122-135.

[21] Y.T. Sul, C. Johansson, E. Byon, et al., The bone response of oxidized bioactive and non-bioactive titanium implants, Biomaterials 26 (2005) 6720-6730.

[22] Y.T. Sul, J. Jonsson, G.S. Yoon, et al., Resonance frequency measurements in vivo and related surface properties of magnesium-incorporated, micropatterned and magnesium-incorporated TiUnite((R)), Osseotite((R)), SLA((R)) and TiOblast((R)) implants, Clin. Oral Implants Res. 20 (2009) 1146-1155.

[23] D. Krupa, J. Baszkiewicz, J. Zdunek, et al., Effect of plasma electrolytic oxidation in the solutions containing $\mathrm{Ca}, \mathrm{P}, \mathrm{Si}, \mathrm{Na}$ on the properties of titanium, J. Biomed. Mater. Res. B 100B (2012) 2156-2166.

[24] C. Della Valle, L. Visai, M. Santin, et al., A novel antibacterial modification treatment of titanium capable to improve osseointegration, Int. J. Artif. Organs 35 (2012) 864-875.

[25] A. Zareidoost, M. Yousefpour, B. Ghaseme, et al., The relationship of surface roughness and cell response of chemical surface modification of titanium, J. Mater. Sci. Mater. Med. 23 (2012) 1479-1488.

[26] B.O. Aronsson, J. Lausmaa, B. Kasemo, Glow discharge plasma treatment for surface cleaning and modification of metallic biomaterials, J. Biomed. Mater. Res. 35 (1997) 49-73.

[27] Y.C. Chang, S.W. Feng, H.M. Huang, et al., Surface analysis of titanium biological modification with glow discharge, Clin. Implant Dent. Relat. Res. 17 (2015) 469-475

[28] Y. Yoshijima, K. Murakami, S. Kayama, et al., Effect of substrate surface hydrophobicity on the adherence of yeast and hyphal Candida, Mycoses 53 (2010) 221-226

[29] C.A. Zamperini, L. Carneiro Hde, E.C. Rangel, et al., In vitro adhesion of Candida glabrata to denture base acrylic resin modified by glow-discharge plasma treatment, Mycoses 56 (2013) 134-144.

[30] V.A. Barao, M.T. Mathew, W.G. Assuncao, et al., Stability of cp-Ti and Ti-6Al-4 V alloy for dental implants as a function of saliva $\mathrm{pH}-$ an electrochemical study, Clin. Oral Implants Res. 23 (2012) 1055-1062.

[31] S. Li, J. Ni, X. Liu, et al., Surface characteristics and biocompatibility of sandblasted and acid-etched titanium surface modified by ultraviolet irradiation: an in vitro study, J. Biomed. Mater. Res. Part B Appl. Biomater. 100 (2012) 1587-1598

[32] G.S. Shi, L.F. Ren, L.Z. Wang, et al., $\mathrm{H} 2 \mathrm{O} 2 / \mathrm{HCl}$ and heat-treated Ti-6Al-4 V stimulates pre-osteoblast proliferation and differentiation, Oral Surg. Oral Med. Oral Pathol. Oral Radiol. Endod. 108 (2009) 368-375.

[33] I.S.V. Marques, V.A.R. Barão, N.C. Cruz, et al., Electrochemical behavior of bioactive coatings on cp-Ti surface for dental application, Corros. Sci. 100 (2015) 133-146. 
[34] R.C.C. Rangel, M.E.P. Souza, W.H. Schreiner, et al., Effect of the fluorination of DLC film on the corrosion protection of aluminum alloy (AA 5052), Surf. Coat. Tech. 204 (2010) 3022-3028.

[35] E.C. Combe, B.A. Owen, J.S. Hodges, A protocol for determining the surface free energy of dental materials, Dent. Mater.: Off. Publ. Acad. Dent. Mater. 20 (2004) 262-268.

[36] I. Soriano, A.Y. Martin, C. Evora, et al., Biodegradable implantable fluconazole delivery rods designed for the treatment of fungal osteomyelitis: influence of gamma sterilization, J. Biomed. Mater. Res. A 77 (2006) 632-638.

[37] B. Guggenheim, R. Gmur, J.C. Galicia, et al., In vitro modeling of host-parasite interactions: the 'subgingival' biofilm challenge of primary human epithelial cells, BMC Microbiol. 9 (2009) 280.

[38] R. Gmur, B. Guggenheim, Antigenic heterogeneity of Bacteroides intermedius as recognized by monoclonal antibodies, Infect. Immun. 42 (1983) 459-470.

[39] S. Shapiro, E. Giertsen, B. Guggenheim, An in vitro oral biofilm model for comparing the efficacy of antimicrobial mouthrinses, Caries Res. 36 (2002) 93-100.

[40] B. Guggenheim, E. Giertsen, P. Schupbach, et al., Validation of an in vitro biofilm model of supragingival plaque, J. Dent. Res. 80 (2001) 363-370.

[41] C.P. Aires, A.A. Del Bel Cury, L.M. Tenuta, et al., Effect of starch and sucrose on dental biofilm formation and on root dentine demineralization, Caries Res. 42 (2008) 380-386

[42] L.J. Zylber, H.V. Jordan, Development of a selective medium for detection and enumeration of Actinomyces viscosus and Actinomyces naeslundii in dental plaque, J. Clin. Microbiol. 15 (1982) 253-259.

[43] S. Silva, M. Henriques, A. Martins, et al., Biofilms of non-Candida albicans Candida species: quantification, structure and matrix composition, Med. Mycol. 47 (2009) 681-689.

[44] M. Dubois, K. Gilles, J.K. Hamilton, et al., A colorimetric method for the determination of sugars, Nature 168 (1951) 167.

[45] S.C. Lucena-Ferreira, A.P. Ricomini-Filho, W.J. Silva, et al., Influence of daily immersion in denture cleanser on multispecies biofilm, Clin. Oral Investig. 18 (2014) 2179-2185.

[46] T. Thurnheer, R. Gmur, Guggenheim B: Multiplex FISH analysis of a six-species bacterial biofilm, J. Microbiol. Methods 56 (2004) 37-47.

[47] M. Sowa, M. Piotrowska, M. Widziolek, et al., Bioactivity of coatings formed on Ti-13Nb-13Zr alloy using plasma electrolytic oxidation, Mater. Sci. Eng. C Mater. Biol. Appl. 49 (2015) 159-173.

[48] A. Pae, S.S. Kim, H.S. Kim, et al., Osteoblast-like cell attachment and proliferation on turned, blasted, and anodized titanium surfaces, Int. J. Oral Maxillofac. Implants 26 (2011) 475-481.

[49] D. Krupa, J. Baszkiewicz, J. Zdunek, et al., Effect of plasma electrolytic oxidation in the solutions containing $\mathrm{Ca}, \mathrm{P}, \mathrm{Si}, \mathrm{Na}$ on the properties of titanium, J. Biomed. Mater. Res. Part B Appl. Biomater. 100 (2012) 2156-2166

[50] T. Hayakawa, M. Yoshinari, K. Nemoto, Characterization and protein-adsorption behavior of deposited organic thin film onto titanium by plasma polymerization with hexamethyldisiloxane, Biomaterials 25 (2004) 119-127.

[51] R.A. Gittens, L. Scheideler, F. Rupp, et al., A review on the wettability of denta implant surfaces II: Biological and clinical aspects, Acta Biomater. 10 (2014) 2907-2918

[52] M. Geetha, A.K. Singh, R. Asokamani, et al., Ti based biomaterials, the ultimate choice for orthopaedic implants - a review, Prog. Mater. Sci. 54 (2009) $397-425$.

[53] D.J. Wever, A.G. Veldhuizen, J. de Vries, et al., Electrochemical and surface characterization of a nickel-titanium alloy, Biomaterials 19 (1998) 761-769.

[54] C. Larsson, P. Thomsen, B.O. Aronsson, et al., Bone response to surface-modified titanium implants: studies on the early tissue response to machined and electropolished implants with different oxide thicknesses, Biomaterials 17 (1996) 605-616.

[55] U. Held, D. Rohner, D. Rothamel, Early loading of hydrophilic titanium implants inserted in low-mineralized (D3 and D4) bone: one year results of a prospective clinical trial, Head Face Med. 9 (2013) 37.

[56] H.J. Hu, X.Y. Liu, C.X. Ding, Preparation and cytocompatibility of Si-incorporated nanostructured TiO2 coating, Surf. Coat. Tech. 204 (2010) 3265-3271.

[57] C. Vendemiatti, R.S. Hosokawa, R.C.C. Rangel, et al., Wettability and surface microstructure of polyamide 6 coated with SiOXCYHZ films, Surf. Coat. Tech. 275 (2015) 32-40

[58] Salih Durdu MU, Ali Sabri Berkem, Bioactive coatings on Ti6Al4 V alloy formed by plasma electrolytic oxidation, Surf. Coat. Tech. (2015).

[59] L. Lara Rodriguez, P.A. Sundaram, E. Rosim-Fachini, et al., Plasma electrolytic oxidation coatings on gammaTiAl alloy for potential biomedical applications, J. Biomed. Mater. Res. Part B Appl. Biomater. 102 (2014) 988-1001.

[60] P. Dobrzanski, P. Pawlus, Digital filtering of surface 40 topography: part I. Separation of one-process surface roughness and waviness by Gaussian convolution, Gaussian regression and spline filters, Precis. Eng. 34 (2010) 647-650.

[61] V. Karageorgiou, D. Kaplan, Porosity of 3D biomaterial scaffolds and osteogenesis, Biomaterials 26 (2005) 5474-5491.

[62] P. Gill, V. Musaramthota, N. Munroe, et al., Surface modification of Ni-Ti alloys for stent application after magnetoelectropolishing, Mater. Sci. Eng. C Mater. Biol. Appl. 50 (2015) 37-44.

[63] N.R. Silva, P.G. Coelho, G.B. Valverde, et al., Surface characterization of Ti and Y-TZP following non-thermal plasma exposure, J. Biomed. Mater. Res. Part B Appl. Biomater. 99 (2011) 199-206.
[64] N.A. Krasteva, G. Toromanov, K.T. Hristova, E.I. Radeva, E.V. Pecheva, R.P. Dimitrova, G.P. Altankov, L.D. Pramatarova, Initial biocompatibility of plasma polymerized hexamethyldisiloxane films with different wettability, J. Phys.: Conf. Ser. (2010) 253.

[65] C. Eriksson, H. Nygren, K. Ohlson, Implantation of hydrophilic and hydrophobic titanium discs in rat tibia: cellular reactions on the surfaces during the first 3 weeks in bone, Biomaterials 25 (2004) 4759-4766.

[66] K. Kim, B.A. Lee, X.H. Piao, et al., Surface characteristics and bioactivity of an anodized titanium surface, J. Periodontal Implant Sci. 43 (2013) 198-205.

[67] R.A. Gittens, R. Olivares-Navarrete, Z. Schwartz, et al., Implant osseointegration and the role of microroughness and nanostructures: lessons for spine implants, Acta Biomater. 10 (2014) 3363-3371.

[68] B. Del Curto, M.F. Brunella, C. Giordano, et al., Decreased bacterial adhesion to surface-treated titanium, Int. J. Artif. Organs 28 (2005) 718-730.

[69] D.J. Lin, M.T. Tsai, T.M. Shieh, et al., In vitro antibacterial activity and cytocompatibility of bismuth doped micro-arc oxidized titanium, J. Biomater. Appl. 27 (2013) 553-563.

[70] J. Lv, H. Li, Y. Mu, et al., The adhesion and growth of both the human primary gingival epithelial cells and Streptococcus mutans on micro-arc oxidized titanium, Cell Biochem. Biophys. 70 (2014) 1083-1090.

[71] A. Almaguer-Flores, P. Silva-Bermudez, R. Galicia, et al., Bacterial adhesion on amorphous and crystalline metal oxide coatings, Mater. Sci. Eng. C Mater. Biol. Appl. 57 (2015) 88-99.

[72] W. Custodio, W.J. Silva, A.F. Paes Leme, et al., Plasma proteins in the acquired denture pellicle enhance substrate surface free energy and Candida albicans phospholipase and proteinase activities, J. Investig. Clin. Dent. 6 (2015) 273-281.

[73] C.G. Dodo, P.M. Senna, W. Custodio, et al., Proteome analysis of the plasma protein layer adsorbed to a rough titanium surface, Biofouling 29 (2013) 549-557.

[74] S. Schlafer, B. Riep, A.L. Griffen, et al., Filifactor alocis-involvement in periodontal biofilms, BMC Microbiol. 10 (2010) 66.

[75] A.H. Rickard, P. Gilbert, N.J. High, et al., Bacterial coaggregation: an integral process in the development of multi-species biofilms, Trends Microbiol. 11 (2003) 94-100.

[76] R.M. Donlan, Biofilms: microbial life on surfaces, Emerg. Infect. Dis. 8 (2002) $881-890$

[77] E. Yoshida, T. Hayakawa, Adsorption study of pellicle proteins to gold, silica and titanium by quartz crystal microbalance method, Dent. Mater. J. 32 (2013) 883-887

[78] K. Bao, G.N. Belibasakis, N. Selevsek, et al., Proteomic profiling of host-biofilm interactions in an oral infection model resembling the periodontal pocket, Sci. Rep. 5 (2015) 15999.

[79] G.N. Belibasakis, A. Meier, B. Guggenheim, et al., The RANKL-OPG system is differentially regulated by supragingival and subgingival biofilm supernatants, Cytokine 55 (2011) 98-103.

[80] W. Zhang, J. Sun, W. Ding, et al., Extracellular matrix-associated proteins form an integral and dynamic system during Pseudomonas aeruginosa biofilm development, Front. Cell. Infect. Microbiol. 5 (2015) 40.

[81] M. Quirynen, M. De Soete, D. van Steenberghe, Infectious risks for oral implants: a review of the literature, Clin. Oral Implants Res. 13 (2002) 1-19.

[82] G.R. de Oliveira, L. Pozzer, L. Cavalieri-Pereira, et al., Bacterial adhesion and colonization differences between zirconia and titanium implant abutments: an in vivo human study, J. Periodontal Implant 42 (2012) 217-223.

[83] M.C. Sanchez, A. Llama-Palacios, V. Blanc, et al., Structure, viability and bacterial kinetics of an in vitro biofilm model using six bacteria from the subgingival microbiota, J. Periodontal Res. 46 (2011) 252-260.

[84] V. Blanc, S. Isabal, M.C. Sanchez, et al., Characterization and application of a flow system for in vitro multispecies oral biofilm formation, J. Periodontal Res, 49 (2014) 323-332.

[85] P.E. Kolenbrander, R.J. Palmer Jr., A.H. Rickard, et al., Bacterial interactions and successions during plaque development, Periodontology 2006 (42) (2000) 47-79.

[86] J.L. Mark Welch, B.J. Rossetti, C.W. Rieken, et al., Biogeography of a human oral microbiome at the micron scale, Proc. Natl. Acad. Sci. U. S. A. 113 (2016) E791-800.

[87] K. Nakanishi, T. Sakiyama, K. Imamura, On the adsorption of proteins on solid surfaces, a common but very complicated phenomenon, J. Biosci. Bioeng. 91 (2001) 233-244.

[88] S.D. Knorr, E.C. Combe, L.F. Wolff, et al., The surface free energy of denta gold-based materials, Dent. Mater.: Off. Publ. Acad. Dent. Mater. 21 (2005) $272-277$

[89] M.A. Curtis, G.S. Griffiths, S.J. Price, et al., The total protein concentration of gingival crevicular fluid: variation with sampling time and gingival inflammation, J. Clin. Periodontol. 15 (1988) 628-632.

[90] J.A. Andrade, M. Feres, L.C. Figueiredo, et al., The ability of the BANA Test to detect different levels of P gingivalis, T. denticola and T. forsythia, Braz. Oral Res. 24 (2010) 224-230.

[91] A.M. Romani, A. Giorgi, V. Acuna, et al., The influence of substratum type and nutrient supply on biofilm organic matter utilization in streams, Limnol. Oceanogr. 49 (2004) 1713-1721.

[92] G. Tardif, M.C. Sulavik, G.W. Jones, et al., Spontaneous switching of the sucrose-promoted colony phenotype in Streptococcus-Sanguis, Infect. Immun 57 (1989) 3945-3948. 
[93] L.J. Bergeron, R.A. Burne, Roles of fructosyltransferase and levanase-sucrase of Actinomyces naeslundii in fructan and sucrose metabolism, Infect. Immun. 69 (2001) 5395-5402.

[94] D. Bajrami, V. Hoxha, O. Gorduysus, et al., Cytotoxic effect of endodontic irrigants in vitro, Med. Sci. Monit. Basic Res. 20 (2014) 22-26.

[95] H.M. Zhou, Y. Shen, Z.J. Wang, et al., In vitro cytotoxicity evaluation of a novel root repair material, J. Endod. 39 (2013) 478-483.

[96] S. Marques Ida, M.F. Alfaro, M.T. Saito, et al., Biomimetic coatings enhance tribocorrosion behavior and cell responses of commercially pure titanium surfaces, Biointerphases 11 (2016) 031008.
[97] H.H. Huang, In situ surface electrochemical characterizations of Ti and Ti-6Al-4 V alloy cultured with osteoblast-like cells, Biochem. Biophys. Res. Commun. 314 (2004) 787-792.

[98] R. Burgers, S. Hahnel, T.E. Reichert, et al., Adhesion of Candida albicans to various dental implant surfaces and the influence of salivary pellicle proteins, Acta Biomater. 6 (2010) 2307-2313. 